\title{
Synthesis, of some transition metal (II/III)-Schiff base complexes and copper, zinc nanoparticle size bearing sulfonamide fragment : New drugs for antimicrobial and anticancer agents.
}

\author{
*A. A. Salman, *Carmen M.Sharaby, ${ }^{* *}$ Abdel Fatah. M. B, Fatma M.A. \\ * Chemistry Department, Faculty of Science, Al-Azhar University (Girls), Nasr City, Cairo, Egypt. \\ ** Applied Chemistry, Institute Research Petroleum, Nasr City, Cairo, Egypt.
}

\begin{abstract}
A simple approach to the synthesis metal complexes and copper, zinc nano particles size (CuNPs, ZnNPs) of novel Schiff base of sulfonamide ligand (HL) resulted from the condensation of sulfametrole [N'-(4-methoxy-1,2,5-thiadiazol-3-yl]sulfanilamide and 1-(2-Furanyl) ethanon. The metal complexes and copper, zinc nano particles size (CuNPs, ZnNPs) of HL ligand were synthesized and characterized using different physico-chemical studies as elemental analyses, mass spectra, conductivity measurement, UV-vis Spectra, solid reflectance, IR spectra, ${ }^{1} \mathrm{H}$ NMR spectra, magnetic susceptibility, thermal analyses (TGA and DTA), (TEM) Transmission Electron Microscope and their microbial and anticancer activities . The spectroscopic data of the complexes suggest their 1:2(L:M) complex structures. Also the spectroscopic studies suggested the octahedral structure for all complexes. The size and morphology investigation of copper and zinc nano particles (CuNPs, ZnNPs) with (HL) ligand by TEM images indicate that the copper and zinc nano (CuNPs, ZnNPs) show spherical shape with core shell of HL ligand. The synthesized Schiff base and its metal complexes, CuNPs, ZnNPs were screened for their bacterial, antifungal and anticancer activity. The activity data show that the metal complexes, CuNPs and ZnNPs to be more potent than the parent HL Schiff base ligand. Also the data show that the CuNPs and ZnNPs more potent than the metal complexes and than HL free ligand .
\end{abstract}

Keywords: New Schiff base of sulfonamide, transition metal complexes, CuNPs, ZnNPs and antimicrobial, anticancer activity.

\section{Introduction}

Schiff bases are an important class of organic compounds ${ }^{(1.2)}$. They were first reported by Hugo Schiff in $1864^{(2)}$. The Schiff base ligands and their corresponding metal complexes have expanded enormously and include a vast area of organometallic compounds and various aspects of bioinorganic chemistry ${ }^{(3)}$. Schiff base ligands have been reported to show a variety of biological actions by virtue of the azomethine linkage, which is responsible for various antibacterial, antifungal, herbicidal,clinical and analytical activities ${ }^{(4)}$. Transition metal complexes with oxygen and nitrogen donor Schiff bases are of particular interest ${ }^{(5,6)}$, because of their ability to possess unusual configuration ${ }^{(3)}$. On the other hand, azo compounds are very important molecules and have attracted much attention in both academic and applied research ${ }^{(3)}$. Azo compounds and their metal complexes are known to be involved in a number of biological reactions, such as inhibition of DNA,RNA, and protein synthesis, nitrogen fixation, and carcinogenesis $^{(7)}$. Schiff bases derived from aromatic amines and aromatic aldehyde have a wide variety of applications in many fields as sulfonamide Schiff bases which 
have been reported to posses-antimicrobial $^{(8)}$, anti-inflammatory activity ${ }^{(29)}$, antikinetoplastid antimitotic activity ${ }^{(29)}$, antitumor activity and anticonvulsant activity $^{(9)}$. The present work was devoted to elucidating the structures of new series of $\mathrm{Fe}(\mathrm{III}), \mathrm{Fe}(\mathrm{II}), \mathrm{Cu}(\mathrm{II}), \mathrm{Zn}(\mathrm{II}), \mathrm{Cd}(\mathrm{II}), \mathrm{Ce}(\mathrm{III})$, $\mathrm{UO}_{2}$ (II) complexes and copper, zinc metal nanoparticles (CuNps,ZnNps) with HL Schiff base ligand 4-(1-Furan-2-yl-ethylideneamino)-N-(4-methoxy-1,2,5- thiadiazol-3-yl)benzenesulfonamide and to check their biological activities $^{(2)}$.

Nanocomposites are composites in which at least one of the phases shows dimensions in the nanometre range $(1 \mathrm{~nm}=$ $\left.10^{-9} \mathrm{~m}\right)^{(10)}$. Nanocomposite materials have emerged as suitable alternatives to overcome limitations of microcomposites and monolithics, while posing preparation challenges related to the control of elemental composition and stoichiometry in the nanocluster phase. They are reported to be the materials of $21^{\text {st }}$ century in the view of possessing design uniqueness and property combinations that are not found in conventional composites ${ }^{(10)}$. The general understanding of these properties is yet to be reached, even though the first inference on them was reported as early as $1992^{(10)}$.

\section{Experimental}

\subsection{Materials and reagents}

All chemicals used were of the analytical reagent grade(AR), and of highest purity available. Sulphametrole, 1-(2furanyl)-ethanone and ferric chloride hexahydrate $\left(\mathrm{FeCl}_{3} \cdot 6 \mathrm{H}_{2} \mathrm{O}\right)$, ferrous sulphate heptahydrate $\left(\mathrm{FeSO}_{4} .7 \mathrm{H}_{2} \mathrm{O}\right)$, copper chloride dihydrate $\left(\mathrm{CuCl}_{2} \cdot 2 \mathrm{H}_{2} \mathrm{O}\right)$, zinc chloride anhydrous $\left(\mathrm{ZnCl}_{2}\right)$, cadmium chloride monohydrate $\left(\mathrm{CdCl}_{2} \cdot \mathrm{H}_{2} \mathrm{O}\right)$, cerum chloride anhydrous $\left(\mathrm{CeCl}_{3}\right)$ and uranyl nitrate anhydrous $\mathrm{UO}_{2}\left(\mathrm{NO}_{3}\right)_{2}$ and copper, zinc metal nano particles (CuNps,ZnNps) were purchased from (B.D.H Merck, Sigma or Fluka) and the organic solvents (ethanol, diethylether, deutrated dimethylsulfoxide (DMSO), and dimethyl formamide (DMF), were purchased from BDH. Perchloric acid, ammonium nitrate, ammonia solution, ammonium chloride, nitric acid, potassium dichromate and ethylenediamintetraacetic acid disodium salt (EDTA) were BDH or Merck products. Murexide, Eriochrom black-T(EBT) were used as indicators BDH or Merck products. De-ionized water collected from all glass equipments was usually used in all preparations.

\subsection{Instrumentation}

The molar conductance measurements of complexes were carried out in DMF $\left(10^{-3} \mathrm{M}\right)$ using a Jenway 4510 conductivity meter. Elemental analyses of the separated solids for $\mathrm{C}, \mathrm{H}, \mathrm{N}, \mathrm{S}$ and $\mathrm{Cl}$ were performed at the Microanalytical Center,Cairo University, Giza, Egygpt. The UV-vis absorption spectra and solid reflectance were measured at room temperature in UV-vis range(200-800nm) using Shimadzu PC 3101 UV-vis spectrophotometer, at the Regina Center for Mycology Biotechnology, Al-azhar University , Cairo, Egypt.Infrared spectra were recorded, as $\mathrm{KBr}$ pellets, on a PerkinElmer FT-IR type 1650 spectrophotometer in wave number region $4000-400 \mathrm{~cm}^{-1}$. ${ }^{1} \mathrm{H}$ NMR spectra (DMSO-d6) were recorded with Bruker FT-400MHZ spectrometer. Chemical shift for proton resonances were reported in $\operatorname{ppm}(\delta)$ relative to tetramethylsilane(TMS).The molar magnetic susceptibility was measured on powdered samples using the Faraday method. The diamagnetic corrections were made by Pascal's constant and $\mathrm{Hg}\left[\mathrm{Co}(\mathrm{SCN})_{4}\right]$ was used as a calibrant. Thermal analyses (TGA and DTA) the prepared complexes were carried out in dynamic nitrogen atmosphere $\left(20 \mathrm{~mL} \mathrm{~min}^{-1}\right)$ with heating rate of $10^{\circ} \mathrm{Cmin}^{-1}$ using Shimadzu TGA-50H and DTA-50H at Cairo University, Egypt. The percent weight loss was measured from ambient temperature up to $1000^{\circ} \mathrm{C}$, where highly sintered $\alpha-\mathrm{Al}_{2} \mathrm{O}_{3}$ was used as a reference. Transmission electron microscopy (TEM) images were obtained by using a Jeol 2010 named DV $300 \mathrm{~W} 1$ system operating at 130 $\mathrm{kV}$. TEM images were used to determine the partical size.

\subsection{Synthesis of Schiff base (HL)}

Schiff base ligand HL was prepared by mixing hot ethanolic solution $\left(\approx 60^{\circ} \mathrm{C}\right)$ 
of the ketone, 1-(2-furanyl)-ethanone $(5.46 \mathrm{~g}$, $0.05 \mathrm{mmol})$ to hot ethanolic solution $\left(\approx 60^{\circ} \mathrm{C}\right)$ of sulphametrole, [N'-(4-methoxy$1,2,5$ - thiadiazole-3-yl) sulfanil-amide] $(14.361 \mathrm{~g}, 0.05 \mathrm{mmol})$ in $50 \mathrm{ml}$ quickfit flask. The reaction mixture was heated under reflux for $\approx 3$ hr under anhydrous conditions with continuous stirring and the formed solid product was separated by filtration, purified by crystallization from ethanol, washed with diethyl ether and dried in vacuum over anhydrous calcium chloride. The yield of brown crystals of HL was $94 \%$ with m.p $=180^{\circ} \mathrm{C}$.

\subsection{Synthesis of metal complexes}

The metal complexes of HL ligand were prepared in 1:2 (L:M) molar ratio. The complexes were prepared by the addition $25 \mathrm{ml}$ hot ethanolic solution $\left(\approx 60^{\circ} \mathrm{C}\right)$ of metal chloride or nitrate or sulphate (2mmol) to $25 \mathrm{ml}$ hot ethanolic solution $\left(\approx 60^{\circ} \mathrm{C}\right.$ ) of Schiff base (1mmol).The resulting mixture was stirred under reflux for $\approx_{2} \mathrm{hr}$ where upon the colored complexes precipitated. They were separated by filtration, purified by crystallization from ethanol, washed several times with diethyl ether and dried under vacuo.

\subsection{Synthesis of copper or zinc metals nanocomposites (CuNPs, ZnNPs).}

The nanocomposite were prepared by addition $2 \mathrm{~g}$ of copper or zinc nanoparticles (CuNps,ZnNps) were dissolved to (10ml) in N,N-dimethyl formamide (DMF) and then were slowly mixed with $1 \mathrm{~g}$ of Schiff-base(HL) dissolved to (10ml) in N,Ndimethyl formamide (DMF). The mixture was stirred for $24 \mathrm{~h}$ at room temperature and then dried under vacuum. After the removal of DMF, the nanoparticle composites were formed .The composites were washed several times with DMF and diethyl ether and almost no free Schiff-base could be found in the solution, indicating that almost all of ligand (HL) has been combined with the copper or zinc nanoparticle and the content of copper or zinc metals in Schiffbase was $66.66 \%$.

\subsection{Biological activity}

This paper aims to the discovery of new metal complexes and nanoparticle composite compounds against new target which is a matter of urgency. So the antimicrobial and antitumor activity of the new synthesized free Schiff base ligand HL and its metal complexes and nanoparticle composites were studied.

The free Schiff-base ligand (HL) and its metal complexes and nanoparticle composites were screened against microorganism,Gram positive (+ve) bacteria; Staphylococcus aureus (ATCC 25923) and Bacillus subtilis(ATCC 6635), Gram negative(-ve) bacteria Salmonella typhimurium (ATCC 14028) and Escherichia coli (ATCC 25922), Yeast; Candida albicans (ATCC 10231) and fungi; Aspergillus fumigatus to assess their potential antibacterial and antifungal activities. The antibiotic, Chloramphenicol and Cephalothin were used as standard antibacterial control and Cyloheximide as standard Yeasts and Fungi control using agar mutrient as the medium. The test solutions of two concentrations, $1 \mathrm{mg} / \mathrm{L}$ and $0.5 \mathrm{mg} / \mathrm{L}$ were prepared by dissolving the newly synthized compounds in DMF as a solvent, then poured on agar medium with microorganisms. At $35^{\circ} \mathrm{C}$ for $24 \mathrm{hr}$ during this time the tested solution diffused and the growth of inoculated microorganisms were affected. The inhibition zone appear on the plate was measured $^{(1)}$. The action of the free HL ligand and that its metal complexes against bacterial, Yeasts and Fungal species were recorded in Tables 8,9. The in-vitro anticancer activity evaluation of the newly synthesized compounds HLligand and their metal complexes and nanocomposites was carried out against human cancer cell line (HCT-116) (human colon cancer cell lien).

\section{Results and discussion}

\subsection{Schiff base characterization}

The new prepared HL Schiff-base ligand, 4-(1-Furan-2-yl-ethylideneamino)$\mathrm{N}$ - (4methoxy-[1,2,5]thiadiazol-3-yl) benzen sulfonamide was subjected to elemental analyses, mass spectra, IR and ${ }^{1} \mathrm{H}$ NMR spectral studies. The results of elemental analyses $(\mathrm{C}, \mathrm{H}, \mathrm{N}, \mathrm{S}$ and $\mathrm{Cl})$ and the 
suggested molecular formula of $\mathrm{HL}$ $\left(\mathrm{C}_{15} \mathrm{H}_{14} \mathrm{~N}_{4} \mathrm{O}_{4} \mathrm{~S}_{2}\right)$ and Table 1 are shown in Figure 1. The melting point are presented in Table 1. The melting point of HL Schiff base ligand is sharp indicating the purity of this new prepared ligand. The mass spectra Figure 2, Schem 1 show the mole- cular ion peak at $\mathrm{m} / \mathrm{z}=378(3 \%)$, which compatible with molecular formula $\mathrm{C}_{15} \mathrm{H}_{14} \mathrm{~N}_{4} \mathrm{O}_{4} \mathrm{~S}_{2}$ of HL Schiff base ligand. The base peak appeared at $\mathrm{m} / \mathrm{z}=77(100 \%)$ was recorded to HL ligand. The other mass fragmentation patterns are shown in Figure 2, Schem 1 . The UV-vis spectrum of HL Schiff base ligand was recorded in $\left(10^{-3} \mathrm{M}\right)$ DMF as solvent. The spectrum show the characteristic absorption bands at $\lambda_{\max }=284 \mathrm{~nm}, \lambda_{\max }=368 \mathrm{~nm}$ which can by assigned to $\pi-\pi^{*}$ and $n-\pi^{*}$ transitions respectively for HL Schiff base ligand ${ }^{(11,12)}$, Table 4. The IR spectral data, Table 2 in the region $4000-400 \mathrm{~cm}^{-1}$ have been recorded for the HL Schiff base ligand. The IR data show that the $\mathrm{v}(\mathrm{CH}=\mathrm{N})$ of the azomethine group and $\mathrm{v}(\mathrm{C}=\mathrm{N})$ of the thiadiazole moiety occur at $1596 \mathrm{~cm}^{-1}$ and $1629 \mathrm{~cm}^{-1}$, respectively ${ }^{(13-15)}$. In addition, the ligand exhibits two bands at 1330 and $1130 \mathrm{~cm}^{-1}$ which is attributed to $\mathrm{v}\left(\mathrm{SO}_{2}\right)_{\text {asym }}$ and $\mathrm{v}\left(\mathrm{SO}_{2}\right)_{\text {sym }}$ stretching vibrations, respectively ${ }^{(16,17)}$. Also, it has a band at $3452 \mathrm{~cm}^{-1}$ which attributed to $\mathrm{v}(\mathrm{NH})^{(12)}$. The ${ }^{1} \mathrm{H}$ NMR data for $\mathrm{HL}$ Schiff base ligand, Table 5, are recorded in DMSO- $d 6^{(18-20)}$, which show sharp signals at 2.59 and 3.94 ppm which may be assigned to the $\left(-\mathrm{CH}_{3}=\mathrm{N}, 3 \mathrm{H}\right)$ and $(-\mathrm{OCH} 3 ; 3 \mathrm{H})$ protons $^{(21,22)}$, respectively. Another doubletdoublet band observed at 7.54-7.59ppm for HL Schiff base ligand assigned to the p-di substituted benzene ring $(23,24)$. The broad band observed at $11.25 \mathrm{ppm}$ may be attributed to the secondary amine proton ($\left.\mathrm{SO}_{2}-\mathrm{NH} ; 1 \mathrm{H}\right)$ (exchangeable with $\left.\mathrm{D}_{2} \mathrm{O}\right)^{(20,22)}$.

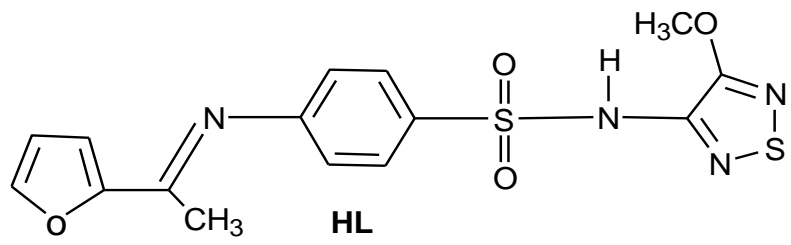

Fig.1. suggested structure of newly synthesized HL Schiff base ligand.

Table 1. Elemental analyses and some physical measurements of HL Schiff base ligand and its metal complexes (1-7).

\begin{tabular}{|c|c|c|c|c|c|c|c|c|c|}
\hline \multirow[t]{2}{*}{ Compd. No. Emprical formula } & \multirow{2}{*}{$\begin{array}{l}\text { M.P. } \\
\left({ }^{\circ} \mathrm{C}\right)\end{array}$} & \multirow{2}{*}{$\begin{array}{l}\text { Color } \\
\text { (Yield \%) }\end{array}$} & \multicolumn{6}{|c|}{ (\%) found (Calcd.) } & \multirow{2}{*}{$\begin{array}{c}\Lambda m \\
\Omega^{-1} \mathrm{~mol}^{-1} \mathrm{~cm}^{2}\end{array}$} \\
\hline & & & C & $\mathrm{H}$ & $\mathbf{N}$ & $\mathbf{S}$ & $\mathrm{CL}$ & M & \\
\hline $\begin{array}{c}\mathrm{HL} \\
\mathrm{C}_{15} \mathrm{H}_{14} \mathrm{~N}_{4} \mathrm{O}_{4} \mathrm{~S}_{2} .378\end{array}$ & 180 & $\begin{array}{l}\text { Brown } \\
(94)\end{array}$ & $\begin{array}{c}47.61 \\
(47.35)\end{array}$ & $\begin{array}{c}3.70 \\
(3.92)\end{array}$ & $\begin{array}{l}14.80 \\
(14.5)\end{array}$ & $\begin{array}{l}16.90 \\
(17.1)\end{array}$ & - & - & 9.66 \\
\hline $\begin{array}{l}(1)\left[\left(\mathrm{FeCl}_{3}\right)_{2}(\mathrm{HL})\left(\mathrm{H}_{2} \mathrm{O}\right)_{2}\right] \cdot \mathrm{H}_{2} \mathrm{O} \\
\mathrm{C}_{15} \mathrm{H}_{24} \mathrm{Cl}_{6} \mathrm{Fe}_{2} \mathrm{~N}_{6} \mathrm{O}_{9} \mathrm{~S}_{2} .734\end{array}$ & $>300$ & $\begin{array}{l}\text { Dark green } \\
\quad(72)\end{array}$ & $\begin{array}{l}24.37 \\
(24.15)\end{array}$ & $\begin{array}{c}1.89 \\
(1.45)\end{array}$ & $\begin{array}{l}7.58 \\
(7.80)\end{array}$ & $\begin{array}{c}8.66 \\
(8.11)\end{array}$ & $\begin{array}{c}29.23 \\
(29.01)\end{array}$ & $\begin{array}{c}15.10 \\
(15.80)\end{array}$ & 28.58 \\
\hline $\begin{array}{l}(2)\left[\left(\mathrm{FeSO}_{4}\right)_{2}(\mathrm{HL})\left(\mathrm{H}_{2} \mathrm{O}\right)_{4}\right] \cdot \mathrm{H}_{2} \mathrm{O} \\
\mathrm{C}_{15} \mathrm{H}_{24} \mathrm{Fe}_{2} \mathrm{~N}_{6} \mathrm{O}_{17} \mathrm{~S}_{4} \cdot 771.60\end{array}$ & $>300$ & $\begin{array}{l}\text { Coffe } \\
(77.20)\end{array}$ & $\begin{array}{l}23.88 \\
(23.90)\end{array}$ & $\begin{array}{c}1.85 \\
(1.64)\end{array}$ & $\begin{array}{c}7.43 \\
(7.62)\end{array}$ & $\begin{array}{c}8.49 \\
(8.24)\end{array}$ & - & $\begin{array}{c}14.80 \\
(15.30)\end{array}$ & 20.21 \\
\hline $\begin{array}{l}(3)\left[\left(\mathrm{CuCl}_{2}\right)_{2}(\mathrm{HL})\left(\mathrm{H}_{2} \mathrm{O}\right)_{4}\right] \cdot \mathrm{H}_{2} \mathrm{O} \\
\mathrm{C}_{15} \mathrm{H}_{24} \mathrm{Cl}_{4} \mathrm{Cu}_{2} \mathrm{~N}_{4} \mathrm{O}_{9} \mathrm{~S}_{2} .736\end{array}$ & $>300$ & $\begin{array}{l}\text { Dark brown } \\
(90.80)\end{array}$ & $\begin{array}{l}25.03 \\
(25.64)\end{array}$ & $\begin{array}{c}1.94 \\
(1.55)\end{array}$ & $\begin{array}{l}7.78 \\
(7.92)\end{array}$ & $\begin{array}{l}8.90 \\
(9.11)\end{array}$ & $\begin{array}{c}19.36 \\
(19.29)\end{array}$ & $\begin{array}{c}17.61 \\
(18.10)\end{array}$ & 21.57 \\
\hline $\begin{array}{l}(4)\left[\left(\mathrm{ZnCl}_{2}\right)_{2}(\mathrm{HL})\left(\mathrm{H}_{2} \mathrm{O}\right)_{4}\right] \cdot \mathrm{H}_{2} \mathrm{O} \\
\mathrm{C}_{15} \mathrm{H}_{24} \mathrm{Cl}_{4} \mathrm{~N}_{6} \mathrm{O}_{9} \mathrm{~S}_{2} \mathrm{Zn}_{2} .640 .8\end{array}$ & $>300$ & $\begin{array}{l}\text { Faint brown } \\
(85.40)\end{array}$ & $\begin{array}{l}24.90 \\
(24.42)\end{array}$ & $\begin{array}{c}1.93 \\
(1.74)\end{array}$ & $\begin{array}{c}7.74 \\
(7.70)\end{array}$ & $\begin{array}{l}8.90 \\
(9.11)\end{array}$ & $\begin{array}{c}22.07 \\
(22.15)\end{array}$ & $\begin{array}{c}17.58 \\
(17.99)\end{array}$ & 25.90 \\
\hline $\begin{array}{l}(5)\left[\left(\mathrm{CdCl}_{2}\right)_{2}(\mathrm{HL})\left(\mathrm{H}_{2} \mathrm{O}\right)_{4}\right] \cdot \mathrm{H}_{2} \mathrm{O} \\
\mathrm{C}_{15} \mathrm{H}_{24} \mathrm{Cd}_{2} \mathrm{Cl}_{4} \mathrm{~N}_{6} \mathrm{O}_{9} \mathrm{~S}_{2} .834\end{array}$ & $>300$ & $\begin{array}{l}\text { Faint coffe } \\
\qquad(96)\end{array}$ & $\begin{array}{l}22.03 \\
(22.41)\end{array}$ & $\begin{array}{c}1.71 \\
(1.82)\end{array}$ & $\begin{array}{c}6.85 \\
(6.34)\end{array}$ & $\begin{array}{l}8.85 \\
(8.92)\end{array}$ & $\begin{array}{c}17.32 \\
(17.02)\end{array}$ & $\begin{array}{c}17.51 \\
(17.92)\end{array}$ & 19.00 \\
\hline $\begin{array}{l}(6)\left[\left(\mathrm{CeCl}_{3}\right)_{2}(\mathrm{HL})\left(\mathrm{H}_{2} \mathrm{O}\right)_{2}\right] \cdot \mathrm{H}_{2} \mathrm{O} \\
\mathrm{C}_{15} \mathrm{H}_{24} \mathrm{Ce}_{2} \mathrm{Cl}_{6} \mathrm{~N}_{6} \mathrm{O}_{9} \mathrm{~S}_{2} .820 .70\end{array}$ & $>300$ & $\begin{array}{l}\text { Faint brown } \\
(70.90)\end{array}$ & $\begin{array}{c}19.84 \\
(19.52)\end{array}$ & $\begin{array}{c}1.54 \\
(1.32)\end{array}$ & $\begin{array}{c}6.17 \\
(6.47)\end{array}$ & $\begin{array}{c}7.83 \\
(7.91)\end{array}$ & - & - & 11.85 \\
\hline $\begin{array}{l}(7)\left[\left(\mathrm{UO}_{2}\right)_{2}(\mathrm{HL})\left(\mathrm{NO}_{3}\right)_{4}\right] \cdot \mathrm{H}_{2} \mathrm{O} \\
\mathrm{C}_{15} \mathrm{H}_{15} \mathrm{~N}_{8} \mathrm{O}_{21} \mathrm{~S}_{2} \mathrm{U}_{2} .118\end{array}$ & $>300$ & $\begin{array}{l}\text { Brown } \\
(71)\end{array}$ & $\begin{array}{c}15.45 \\
(15.83)\end{array}$ & $\begin{array}{c}1.28 \\
(1.26)\end{array}$ & $\begin{array}{c}9.57 \\
(9.54)\end{array}$ & $\begin{array}{l}28.66 \\
(28.37)\end{array}$ & - & - & 18.73 \\
\hline
\end{tabular}




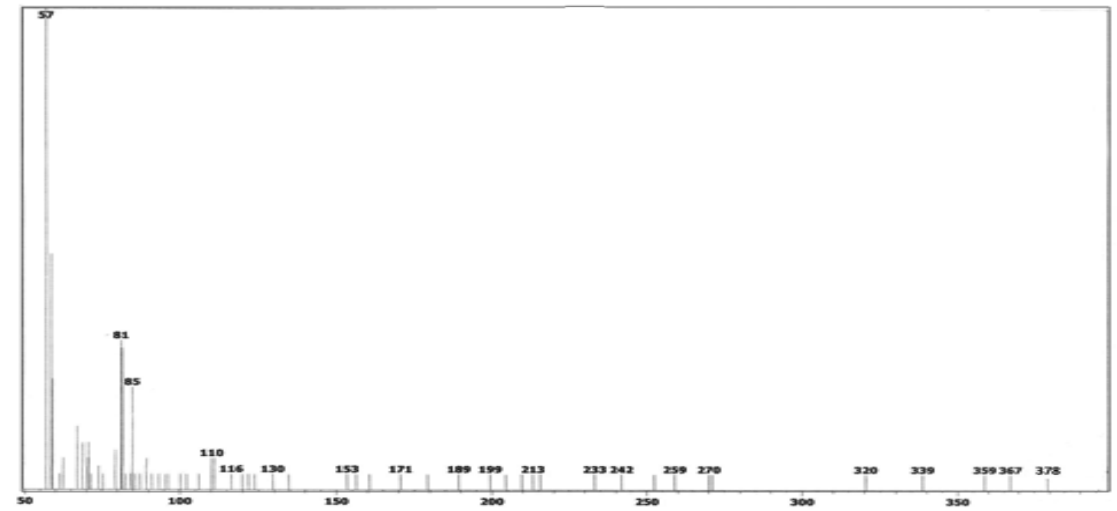

Fig.2. Mass spectrum for HL Schiff base ligand.

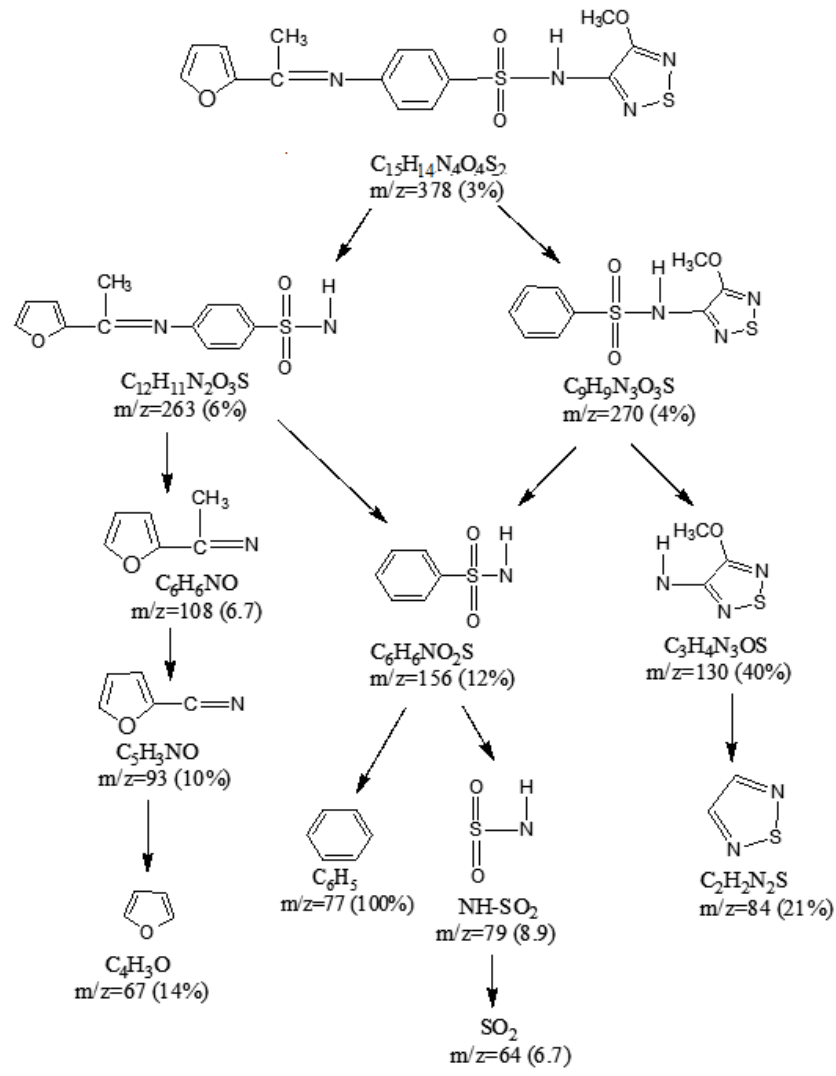

Scheme 1. Mass fragmentation pattern of HL Schiff base free ligand.

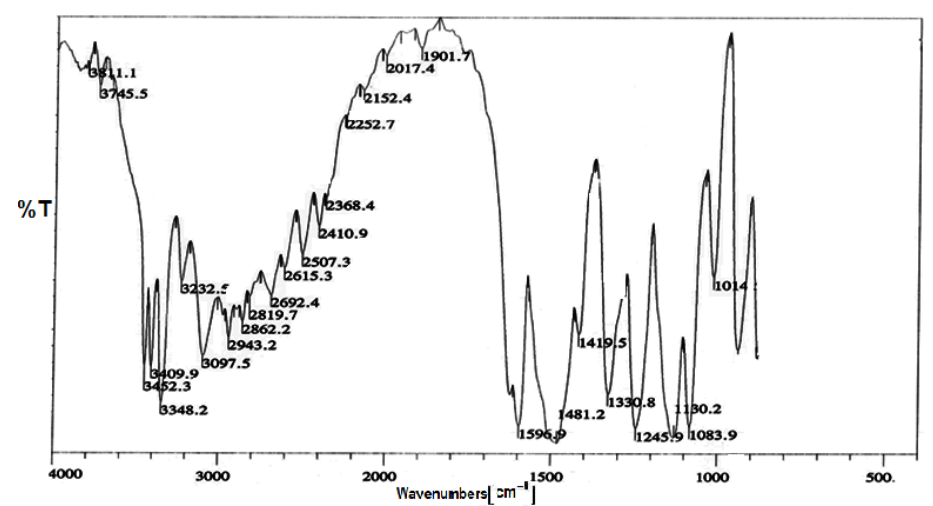

Fig.3 . IR spectrum for HL Schiff-base ligand. 
Table 2. IR spectra $\left(4000-500 \mathrm{~cm}^{-1}\right)$ of the HL Schiff base ligand and its metal complexes (1 -7).

\begin{tabular}{|c|c|c|c|c|c|c|c|c|c|}
\hline Complexes.Compd. No. & $\mathrm{v}(\mathrm{NH})$ & $\begin{array}{l}\mathrm{v}(\mathrm{OH}) \\
\text { enolic }\end{array}$ & $\begin{array}{l}\mathrm{v}\left(\mathrm{SO}_{2}\right) \\
\text { (asym.) }\end{array}$ & $\begin{array}{l}\mathrm{v}\left(\mathrm{SO}_{2}\right) \\
\text { (sym.) }\end{array}$ & $\begin{array}{l}v(C=N) \\
\text { thiodiaza. }\end{array}$ & $\begin{array}{c}\mathrm{v}(\mathrm{CH}=\mathrm{N}) \\
\text { azomethine }\end{array}$ & $\begin{array}{l}\mathrm{v}\left(\mathrm{H}_{2} \mathrm{O}\right) \\
\text { (Coord I } \\
\text { Lattic.) }\end{array}$ & $v(M-0)$ & $\mathrm{v}(\mathrm{M}-\mathrm{N})$ \\
\hline $\mathrm{HL}$ & $3452 \mathrm{br}$ & -- & $1330 \mathrm{br}$ & 1130sh & 1629br & 1596sh & -- & -- & -- \\
\hline (1) $\left[\left(\mathrm{FeCl}_{3}\right)_{2}(\mathrm{HL})\left(\mathrm{H}_{2} \mathrm{O}\right)_{2}\right] \cdot \mathrm{H}_{2} \mathrm{O}$ & -- & $3336 \mathrm{br}$ & $1312 \mathrm{~m}$ & $1165 \mathrm{br}$ & 1616sh & $1595 w$ & $825 \mathrm{br}$ & $542 w$ & $472 w$ \\
\hline (2) $\left[\left(\mathrm{FeSO}_{4}\right)_{2}(\mathrm{HL})\left(\mathrm{H}_{2} \mathrm{O}_{4}\right] \mathrm{H}_{2} \mathrm{O}\right.$ & -- & $3332 \mathrm{sh}$ & 1325sh & $1153 \mathrm{br}$ & 1600sh & $1512 w$ & $887 \mathrm{~m}$ & 543sh & $466 \mathrm{w}$ \\
\hline$(3)\left[\left(\mathrm{CuCl}_{2}\right)_{2}(\mathrm{HL})\left(\mathrm{H}_{2} \mathrm{O}\right)_{4}\right] \cdot \mathrm{H}_{2} \mathrm{O}$ & -- & $3363 w$ & 1315sh & 1153sh & 1622sh & $1522 m$ & $891 \mathrm{~m}$ & $551 \mathrm{~m}$ & $443 w$ \\
\hline (4) $\left[\left(\mathrm{ZnCl}_{2}\right)_{2}(\mathrm{HL})\left(\mathrm{H}_{2} \mathrm{O}\right)_{4}\right] \cdot \mathrm{H}_{2} \mathrm{O}$ & -- & $3336 \mathrm{br}$ & $1327 w$ & $1153 m$ & $1618 w$ & $1553 w$ & $837 \mathrm{~m}$ & $543 w$ & $422 m$ \\
\hline$(5)\left[\left(\mathrm{CdCl}_{2}\right)_{2}(\mathrm{HL})\left(\mathrm{H}_{2} \mathrm{O}\right)_{4}\right] \cdot \mathrm{H}_{2} \mathrm{O}$ & -- & $3332 \mathrm{sh}$ & 1326sh & 1153sh & $1622 \mathrm{~m}$ & $1593 \mathrm{~m}$ & 887sh & 543sh & $462 \mathrm{br}$ \\
\hline$(6)\left[\left(\mathrm{CeCl}_{3}\right)_{2}(\mathrm{HL})\left(\mathrm{H}_{2} \mathrm{O}\right)_{2}\right] \mathrm{H}_{2} \mathrm{O}$ & -- & $3325 w$ & 1326sh & $1155 \mathrm{sh}$ & $1627 \mathrm{~m}$ & 1597sh & $883 \mathrm{br}$ & $545 \mathrm{~m}$ & 435sh \\
\hline$(7)\left[\left(\mathrm{UO}_{2}\right)_{2}(\mathrm{HL})\left(\mathrm{NO}_{3}\right)_{4}\right] \cdot \mathrm{H}_{2} \mathrm{O}$ & -- & $3375 w$ & $1315 \mathrm{br}$ & 1161sh & $1627 \mathrm{br}$ & $1515 \mathrm{~m}$ & $833 \mathrm{~m}$ & $543 \mathrm{~m}$ & $462 \mathrm{br}$ \\
\hline
\end{tabular}

$\mathrm{sh}=$ sharp, $\mathrm{m}=$ medium, $\mathrm{w}=$ weak

Table 3. ${ }^{1} \mathrm{H}$ NMR data for HL Schiff base ligand and their diamagnetic complexes $(\mathbf{4 , 5 , 7 ) .}$

\begin{tabular}{|c|c|c|c|c|c|c|c|}
\hline \multicolumn{8}{|c|}{ Chemical Shift ( $\delta$ in ppm) } \\
\hline Complexes.Compd. No. & $\begin{array}{c}\text { Aromatic } \\
\text { protons }\end{array}$ & $\begin{array}{l}-\mathrm{SO}_{2} \mathrm{NH} \\
\text { protons }\end{array}$ & $\begin{array}{c}-\mathrm{CH} \\
\text { heterocyclic } \\
\text { protons }\end{array}$ & $\begin{array}{l}\text { Coordinate } \\
\text { water } \\
\text { protons }\end{array}$ & $\begin{array}{l}-\mathrm{OCH}_{3} \\
\text { protons }\end{array}$ & $\begin{array}{c}-\mathrm{OH} \\
\text { enolic } \\
\text { protons }\end{array}$ & $\begin{array}{l}-\mathrm{CH}_{3} \mathrm{C}=\mathrm{N} \\
\text { protons }\end{array}$ \\
\hline $\mathrm{HL}$ & $\begin{array}{c}7.54-7.57 \\
(\mathrm{~d}, 4 \mathrm{H})\end{array}$ & $\begin{array}{l}11.25 \\
(\mathrm{br}, \mathrm{H})\end{array}$ & $\begin{array}{l}6.50 \\
(\mathrm{~s}, \mathrm{H})\end{array}$ & - & $\begin{array}{c}3.94 \\
(\mathrm{~s}, 3 \mathrm{H})\end{array}$ & - & $\begin{array}{c}2.59 \\
(\mathrm{br}, 3 \mathrm{H})\end{array}$ \\
\hline (4) $\left[\left(\mathrm{ZnCl}_{2}\right)_{2}(\mathrm{HL})\left(\mathrm{H}_{2} \mathrm{O}\right)_{4}\right] \cdot \mathrm{H}_{2} \mathrm{O}$ & $\begin{array}{c}7.56-7.59 \\
(\mathrm{~d}, 4 \mathrm{H})\end{array}$ & - & $\begin{array}{l}6.54 \\
(\mathrm{~s}, \mathrm{H})\end{array}$ & $\begin{array}{c}3.43 \\
(\mathrm{br}, 8 \mathrm{H})\end{array}$ & $\begin{array}{c}3.98 \\
(\mathrm{~s}, 3 \mathrm{H})\end{array}$ & $\begin{array}{c}6.00 \\
(\mathrm{br}, \mathrm{H})\end{array}$ & $\begin{array}{c}2.50 \\
(\mathrm{br}, 3 \mathrm{H})\end{array}$ \\
\hline$(5)\left[\left(\mathrm{CdCl}_{2}\right)_{2}(\mathrm{HL})\left(\mathrm{H}_{2} \mathrm{O}\right)_{4}\right] \cdot \mathrm{H}_{2} \mathrm{O}$ & $\begin{array}{c}7.55-7.58 \\
(\mathrm{~d}, 4 \mathrm{H})\end{array}$ & - & $\begin{array}{c}6.53 \\
(\mathrm{~s}, \mathrm{H})\end{array}$ & $\begin{array}{c}3.42 \\
(\mathrm{br}, 8 \mathrm{H})\end{array}$ & $\begin{array}{c}3.98 \\
(\mathrm{~s}, 3 \mathrm{H})\end{array}$ & $\begin{array}{c}6.00 \\
(\mathrm{br}, \mathrm{H})\end{array}$ & $\begin{array}{c}2.50 \\
(\mathrm{br}, 3 \mathrm{H})\end{array}$ \\
\hline (7) $\left[\left(\mathrm{UO}_{2}\right)_{2}(\mathrm{HL})\left(\mathrm{NO}_{3}\right)_{4}\right] \cdot \mathrm{H}_{2} \mathrm{O}$ & $\begin{array}{c}7.56-7.59 \\
(\mathrm{~d}, 4 \mathrm{H})\end{array}$ & - & $\begin{array}{l}6.54 \\
(\mathrm{~s}, \mathrm{H})\end{array}$ & $\begin{array}{c}3.43 \\
(\mathrm{br}, 8 \mathrm{H})\end{array}$ & $\begin{array}{c}3.98 \\
(\mathrm{~S}, 3 \mathrm{H})\end{array}$ & $\begin{array}{c}6.98 \\
(\mathrm{br}, \mathrm{H})\end{array}$ & $\begin{array}{c}2.50 \\
(\mathrm{br}, 3 \mathrm{H})\end{array}$ \\
\hline
\end{tabular}

$\mathrm{s}=$ singlet, $\mathrm{d}=$ doublet, $\mathrm{br}=$ broad

\subsection{Composition and structure of Schiff base complexes}

The isolated solid complexes of $\mathrm{Fe}(\mathrm{III}), \mathrm{Fe}(\mathrm{II}), \mathrm{Cu}(\mathrm{II}), \mathrm{Zn}(\mathrm{II}), \mathrm{Cd}(\mathrm{II}), \mathrm{Ce}(\mathrm{III})$

and $\mathrm{UO}_{2}$ (II) ions with the HL Schiff base ligand were subjected to elemental analyses (C, H, N, S and Cl), IR, ${ }^{1} \mathrm{H}$ NMR, molar conductance, magnetic studies, thermal analyses (TG and DTA) and Transmission electron microscopy (TEM), to identify their tentative formulae in a trial to elucidate their molecular structures. The results of elemental analyses, Table 1, are in good agreement with those required by the proposed formulae Fig. 4. The complexes are insoluble in water and most organic solvents and soluble in DMF and DMSO solvents.

\subsection{Molar conductunce measurements}

By using the relation $\Lambda_{\mathrm{m}}=\mathrm{K} / \mathrm{C}$, the molar conductance of the complexes can be calculated. The metal (II/III) complexes were dissolved in DMF $\left(10^{-3} \mathrm{M}\right)$.Table 1 shows the molar conductance values of the metal complexes which lie in the range $9-28 \mathrm{ohm}^{-1} \mathrm{~mol}^{-1} \mathrm{Cm}^{2}$ which indicate the non-ionic nature of metal complexes ${ }^{(25)}$. Furthermore, it indicates the bonding of the chloride or nitrate or sulphate ions to metal cations ${ }^{(26)}$.

\subsection{IR spectral studies}

A careful comparison of the IR spectra of the metal complexes (1-7) and their parent Schiff base ligand(HL) was listed in Table 2 and shown in Fig. 3. It 
reveals that the spectra of the complexes(1-7) shows absorption bands of the sulphone group of $\mathrm{v}_{\text {asym }}\left(\mathrm{SO}_{2}\right)$ and $\mathrm{v}_{\text {sym }}\left(\mathrm{SO}_{2}\right)$ shifted to lower frequency than its parent HL ligand at $1327-1312 \mathrm{~cm}^{-1}$ and at $1153-1165 \mathrm{~cm}^{-1}$ respectively ${ }^{(14,27)}$.

On the other hand the $\mathrm{v}(\mathrm{NH})$ group disappear in the spectra of the complexes, the disappearance of this $\mathrm{v}(\mathrm{NH})$ and the shift of $\mathrm{SO}_{2}$ stretching vibration bands to lower frequencies attributed to the enolization of the sulfonamide $\left(-\mathrm{SO}_{2} \mathrm{NH}\right)$ group to the enol form $(-\mathrm{SO}(\mathrm{OH})=\mathrm{N})$ as a result of complexation to give more stable six-memberedring ${ }^{(28,29)}$. This transformation would results in the appearance of a new absorption peak of enolic $\mathrm{v}(\mathrm{OH})$ stretching mode at 3375$3325 \mathrm{~cm}^{-1}$ for HL Schiff-base metal complexes ${ }^{(30)}$.

The lower frequencies of the new enolic $\mathrm{OH}$ group shown in the metal complexes Table 2, which indicates the contribution of this group in the coordination $^{(19)}$. Also the new bands observed at $891-825 \mathrm{~cm}^{-1}$ in spectra of metal complexes were attributed to the stretching and out of plane bending vibrations of coordinated water molecules ${ }^{(31,32)}$. This coordinated water molecules were ducted using the thermal gravimetric analyses studies.

The azomethine $\mathrm{v}(\mathrm{CH}=\mathrm{N})$ group was shifted to lower wavenumbers in the spectra of the complexes due to the contribution of this group in the coordination ${ }^{(33)}$. However, the band due to the thiadizole moiety; $\mathrm{v}(\mathrm{C}=\mathrm{N})$ was shifted to lower frequencies at $1627-1600 \mathrm{~cm}^{-1}$ in the spectra of the complexes, suggesting the coordination via thiadiazole nitrogen ${ }^{(34,35)}$.

Also the IR spectra of the metal complexes show two additional of bands at $551-542 \mathrm{~cm}^{-1}$ and at $472-435 \mathrm{~cm}^{-1}$ assigned to $\mathrm{v}(\mathrm{M}-\mathrm{O})$ and $\mathrm{v}(\mathrm{M}-\mathrm{N})$ stretching vibrations respectively ${ }^{(33,34)}$.

\section{5. ${ }^{1} \mathrm{H}$ NMR spectra}

The proton magnetic resonance for the diamagnetic metal complexes $(4,5,7)$ were recorded in DMSO- $d_{6}{ }^{(16,19,20)}$, Table 3. On comparison, the characteristic proton signals of the complexes $\mathrm{Zn}(\mathrm{II}), \mathrm{Cd}(\mathrm{II})$ and $\mathrm{UO}_{2}$ (II) with those of their parent HL Schiff base ligand were shown in Table 3. It is found that upon complexation, enolization of the secondary amine $\left(-\mathrm{SO}_{2} \mathrm{NH}\right)$ of $\mathrm{HL}$ Schiff base ligand also observed and a new enolic

$(-\mathrm{S}(\mathrm{O})(\mathrm{CH}=\mathrm{N}))$ appeared at $\delta=6.00 \mathrm{ppm}$, $\delta=6.00 \mathrm{ppm}, \delta=6.98 \mathrm{ppm}$ for $\mathrm{Zn}(\mathrm{II}), \mathrm{Cd}(\mathrm{II})$ and $\mathrm{UO}_{2}$ (II) complexes respectively ${ }^{(18,29)}$. Meanwhile the laser intense signal assigned to $\left(-\mathrm{CH}_{3} \mathrm{C}=\mathrm{N}\right)$ proton signal observed at $\delta=2.50 \mathrm{ppm} \delta=2.50$ for $\mathrm{Zn}(\mathrm{II}), \mathrm{Cd}(\mathrm{II})$ and $\mathrm{UO}_{2}$ (II) complexes of HL Schiff-base ligand $^{(21)}$.

Furthermore the multiplate signals of the aromatic protons for diamagnetic complexes appeared around $\delta=7.54$ 7.59ppm ${ }^{(23,36,37) \text {. }}$

From the above it camcoloted that HL Shiff base ligand coordinated to the metal ions through two sites, the first one is enolic-OH of sulfonamide group and 1,2,5 thiadiazol-N and the second site azomethine-N and 1-(2-furanyl)-ethanon-O.

\subsection{Electronic spectra and magnetic properties}

The electronic spectra of the metal complexes displayed in $\left(10^{-3} \mathrm{M}\right)$ DMF at room temperature at wavelength range from 200-800nm are shown in Table 4. All the complexes show two main absorption bands similar to the absorption spectrum of the HL Schiff base ligand which are shifted to lower and higher wavelengths in the regions $275-208 \mathrm{~cm}^{-1}, 479-316 \mathrm{~cm}^{-1}$ which assigned to $\pi-\pi^{*}$ and $\mathrm{n}-\pi^{*}$ transitions for the metal complexes, respectively ${ }^{(11,12,21)}$, Table 4. Also $d-d$ transitions in this type of complexes appear in the region $782-692 \mathrm{~cm}^{-}$ 1(27)

From The electronic spectra of complexes, Table 5 is observed that Fe(III) complex exhibit a band at $19.249 \mathrm{~cm}^{-1}$ assigned to ${ }^{6} \mathrm{~A}_{1 \mathrm{~g}} \rightarrow{ }^{5} \mathrm{~T}_{1 \mathrm{~g}}$ transition. Also, the bands observed at $27.173 \mathrm{~cm}^{-1}, 26.595 \mathrm{~cm}^{-1}$ attributed to ${ }^{6} \mathrm{~A}_{1 \mathrm{~g}} \rightarrow{ }^{6} \mathrm{~T}_{2 \mathrm{~g}}(\mathrm{G})$ and $\mathrm{LMCT}$ 
transitions for $\mathrm{Fe}(\mathrm{III})$ complex respectively ${ }^{(28,34,38)}$. The magnetic moment value is 5.34B.M. for $\mathrm{Fe}(\mathrm{III})$ complex, Table 5 which indicates the octahedral geometry around $\mathrm{Fe}(\mathrm{III})$ ions ${ }^{(18,29,36,39)}$.

Moreover the electronic spectrum of Fe(II) complex, Table 5 shows two bands at $17.421 \mathrm{~cm}^{-1}, 23.409 \mathrm{~cm}^{-1}$ for $\mathrm{Fe}(\mathrm{II})$ complex, assignable to ${ }^{5} \mathrm{~T}_{2 \mathrm{~g}} \rightarrow{ }^{2} \mathrm{E}_{\mathrm{g}}$ and LMCT transitions respectively ${ }^{(40,41)}$. The value of the magnetic moment of $\mathrm{Fe}$ (II) complex is 5.46 B.M. which taken as an evidence for the octahedral geometry around $\mathrm{Fe}(\mathrm{II})$ ion $^{(42)}$. The electronic spectrum of $\mathrm{Cu}(\mathrm{II})$ complex , Table 5 exhibit two broad and low intensity bands cantered at $17.286 \mathrm{~cm}^{-1}$, $27.664 \mathrm{~cm}^{-1}$ for the complex assigned to
${ }^{2} \mathrm{E}_{\mathrm{g}} \rightarrow{ }^{2} \mathrm{~T}_{2 \mathrm{~g}}$ and LMCT transitions respectively ${ }^{(31,43)}$. Themagnetic moment measured for the $\mathrm{Cu}$ (II) complex is 2.38B.M. suggesting the octahedral geometry around $\mathrm{Cu}$ (II) ion in the complex ${ }^{(44)}$. The magnetic moment value for $\mathrm{Ce}$ (III) complex is 2.13B.M. which consistent with the presence of one unpaired electron $^{(13,45)}$. The observation of the magnetic moment value of the $\mathrm{Ce}$ (III) complexe indicates the minor participation of 4 -electron in bond formation ${ }^{(45,46)}$.

The other metal complexes of $\mathrm{Zn}(\mathrm{II}), \mathrm{Cd}(\mathrm{II})$ and $\mathrm{UO}_{2}(\mathrm{II})$ are diamagnetic in nature in accordance with the $d^{0}$ or $d^{10}$ configurations. So all complexes have octahedral structures Table 5.

Table 4 . Electronic spectral data of HL Schiff base ligand and its metal complexes (1-7).

\begin{tabular}{|c|c|c|c|}
\hline \multirow[t]{2}{*}{ Complexes.Compd. No. } & \multicolumn{3}{|c|}{ Absorption bands(nm) } \\
\hline & $\pi-\pi^{*}$ & $\mathrm{n}-\pi^{*}$ & $d-d$ transition \\
\hline $\begin{array}{c}\mathrm{HL} \\
(1)\left[\left(\mathrm{FeCl}_{3}\right)_{2}(\mathrm{HL})\left(\mathrm{H}_{2} \mathrm{O}\right)_{2}\right] \cdot \mathrm{H}_{2} \mathrm{O}\end{array}$ & $\begin{array}{c}284 \\
264,230\end{array}$ & $\begin{array}{c}368 \\
358,428\end{array}$ & 692,782 \\
\hline (2) $\left[\left(\mathrm{FeSO}_{4}\right)_{2}(\mathrm{HL})\left(\mathrm{H}_{2} \mathrm{O}\right)_{4}\right] \cdot \mathrm{H}_{2} \mathrm{O}$ & 214 & 354,479 & 715 \\
\hline$(3)\left[\left(\mathrm{CuCl}_{2}\right)_{2}(\mathrm{HL})\left(\mathrm{H}_{2} \mathrm{O}\right)_{4}\right] \cdot \mathrm{H}_{2} \mathrm{O}$ & 208,238 & 335,399 & 728,762 \\
\hline (4) $\left[\left(\mathrm{ZnCl}_{2}\right)_{2}(\mathrm{HL})\left(\mathrm{H}_{2} \mathrm{O}\right)_{4}\right] \cdot \mathrm{H}_{2} \mathrm{O}$ & $\begin{array}{c}274,265,256 \\
245,218\end{array}$ & 366 & - \\
\hline$(5)\left[\left(\mathrm{CdCl}_{2}\right)_{2}(\mathrm{HL})\left(\mathrm{H}_{2} \mathrm{O}\right)_{4}\right] \cdot \mathrm{H}_{2} \mathrm{O}$ & 231 & 398 & - \\
\hline$(6)\left[\left(\mathrm{CeCl}_{3}\right)_{2}(\mathrm{HL})\left(\mathrm{H}_{2} \mathrm{O}\right)_{2}\right] \cdot \mathrm{H}_{2} \mathrm{O}$ & $275,243,218$ & 316,361 & 588,718 \\
\hline$(7)\left[\left(\mathrm{UO}_{2}\right)_{2}(\mathrm{HL})\left(\mathrm{NO}_{3}\right)_{4}\right] \cdot \mathrm{H}_{2} \mathrm{O}$ & 213 & 336 & 一 \\
\hline
\end{tabular}

Table 5 . Magnetic moment and electronic spectral data of HL metal complexes(1-7).

\begin{tabular}{|c|c|c|c|c|}
\hline Complexes.Compd. No. & Geometry & $\mu_{\text {eff }}(B . M)$ & Band assignment & $\begin{array}{l}\text { Absorption } \\
\text { band }\left(\mathrm{cm}^{-1}\right)\end{array}$ \\
\hline (1) $\left[\left(\mathrm{FeCl}_{3}\right)_{2}(\mathrm{HL})\left(\mathrm{H}_{2} \mathrm{O}\right)_{4}\right] \cdot \mathrm{H}_{2} \mathrm{O}$ & Octahedral & 5.34 & $\begin{array}{c}{ }^{6} \mathrm{~A}_{1 \mathrm{~g}} \rightarrow{ }^{5} \mathrm{~T}_{1 \mathrm{~g}} \\
{ }^{6} \mathrm{~A}_{1 \mathrm{~g}} \rightarrow{ }^{6} \mathrm{~T}_{2 \mathrm{~g}}(\mathrm{G}) \\
\mathrm{LMCT}(\mathrm{L} \rightarrow \mathrm{M})\end{array}$ & $\begin{array}{c}17.436,19.249 \\
23.174 \\
26.595\end{array}$ \\
\hline (2) $\left[\left(\mathrm{FeSO}_{4}\right)_{2}(\mathrm{HL})\left(\mathrm{H}_{2} \mathrm{O}\right)_{4}\right] \cdot \mathrm{H}_{2} \mathrm{O}$ & Octahedral & 5.46 & $\begin{array}{c}{ }^{5} \mathrm{~T}_{2 \mathrm{~g}} \rightarrow{ }^{2} \mathrm{E}_{\mathrm{g}} \\
\mathrm{LMCT}(\mathrm{L} \rightarrow \mathrm{M})\end{array}$ & $\begin{array}{l}17.421 \\
23.809\end{array}$ \\
\hline (3) $\left[\left(\mathrm{CuCl}_{2}\right)_{2}(\mathrm{HL})\left(\mathrm{H}_{2} \mathrm{O}\right)_{4}\right] \cdot \mathrm{H}_{2} \mathrm{O}$ & Octahedral & 2.38 & $\begin{array}{c}{ }^{2} \mathrm{E}_{\mathrm{g}} \rightarrow{ }^{2} \mathrm{~T}_{2 \mathrm{~g}} \\
\mathrm{LMCT}(\mathrm{L} \rightarrow \mathrm{M})\end{array}$ & $\begin{array}{l}17.286 \\
27.664\end{array}$ \\
\hline$(4)\left[\left(\mathrm{ZnCl}_{2}\right)_{2}(\mathrm{HL})\left(\mathrm{H}_{2} \mathrm{O}\right)_{4}\right] \cdot \mathrm{H}_{2} \mathrm{O}$ & Octahedral & -- & $d^{10}$ & -- \\
\hline$(5)\left[\left(\mathrm{CdCl}_{2}\right)_{2}(\mathrm{HL})\left(\mathrm{H}_{2} \mathrm{O}\right)_{4}\right] \cdot \mathrm{H}_{2} \mathrm{O}$ & Octahedral & -- & $d^{10}$ & -- \\
\hline (6) $\left[\left(\mathrm{CeCl}_{3}\right)_{2}(\mathrm{HL})\left(\mathrm{H}_{2} \mathrm{O}\right)_{4}\right] \cdot \mathrm{H}_{2} \mathrm{O}$ & Octahedral & 2.13 & -- & -- \\
\hline (7) $\left[\left(\mathrm{UO}_{2}\right)_{2}(\mathrm{HL})\left(\mathrm{NO}_{3}\right)_{4}\right] \cdot \mathrm{H}_{2} \mathrm{O}$ & Octahedral & -- & $d^{10}$ & -- \\
\hline
\end{tabular}

\subsection{Thermal analyses (TGA and DTA)}

The thermogravimetric analyses of the metal complexes were recorded in Tables 6,7. The TGA thermogram of the complex, $\left[(\mathbf{C u C l})_{2}(\mathbf{H L})\left(\mathbf{H}_{2} \mathbf{O}\right)_{4}\right] \cdot \mathbf{H}_{2} \mathbf{O}$, shows three decomposition steps within the temperature range $30-700^{\circ} \mathrm{C}$. The first step within the temperature range $30-220^{\circ} \mathrm{C}$ is related to the loss of $4 \mathrm{H}_{2} \mathrm{O}$ (coordination, lattice) and $\mathrm{C}_{6} \mathrm{H}_{6}$, with a found mass loss of 20.2\% (calcd.20.6\%); the second step with 
an estimated mass loss of $34.5 \%$ (calcd.34.8\%) within the temperature range $220-520^{\circ} \mathrm{C}$ related to the loss of the organic part $\mathrm{C}_{6} \mathrm{H}_{6} \mathrm{NO}$ and $4 \mathrm{Cl}$. The third at the rang $520-700^{\circ} \mathrm{C}$ with an estimated mass loss of $24.7 \%$ (calcd.25.1\%) attributed to the loss of organic part $\mathrm{C}_{3} \mathrm{H}_{4} \mathrm{~N}_{3} \mathrm{O}_{2} \mathrm{~S}_{2}$ leaving $\mathrm{Cu}_{2} \mathrm{O}$ as a metallic residue. The overall weight loss amounts to $81.5 \%$ (calcd.28.5\%).

Also, The thermal decomposition of the complex $\left[\left(\mathbf{U O}_{2}\right)_{2}(\mathbf{H L})\left(\mathbf{N O}_{3}\right)_{4}\right] \cdot \mathbf{H}_{2} \mathbf{O}$, undergoes thermal decomposition pattern in three steps as follows: The first step within the temperature range of $35-210^{\circ} \mathrm{C}$, represents to the loss of $\mathrm{H}_{2} \mathrm{O}$ (lattice), $\mathrm{NO}_{3}$ and $\mathrm{C}_{6} \mathrm{H}_{6}$, with a found mass loss of $12.6 \%$ (calcd. 13.3\%); the second step with an estimated mass loss of $25 \%$ (calcd. $25.2 \%$ ) within the temperature range $210-250^{\circ} \mathrm{C}$ corresponds to the loss of organic part $\mathrm{C}_{6} \mathrm{H}_{6} \mathrm{NO}$ and $4 \mathrm{NO}_{3}$. The third step at the $520-680^{\circ} \mathrm{C}$ with an estimated mass loss $16.2 \%$ (calcd.16.6\%) attributes to loss of organic part $\mathrm{C}_{3} \mathrm{H}_{4} \mathrm{~N}_{3} \mathrm{O}_{3} \mathrm{~S}_{2}$, leaving $2 \mathrm{UO}_{2}{ }^{+2}$ as a metallic residue. The overall weight loss amounts to $53.8 \%$ (calcd.55.1\%).

\subsubsection{Calculation of activation thermo-} dynamic parameters

Table 6. Thermogravimetric results (TG) of $\mathrm{Cu}(\mathrm{II})$ and $\mathrm{UO}_{2}(\mathrm{II})$ complexes $(\mathbf{3}, \mathbf{7})$.

\begin{tabular}{|c|c|c|c|c|c|c|}
\hline \multirow[b]{2}{*}{ Complexes.Compd. No. } & \multicolumn{5}{|c|}{$\begin{array}{l}\text { Loss in weight } \\
\text { Estim. / (calcd.)\% }\end{array}$} & \multirow[b]{2}{*}{$\begin{array}{l}\text { Metallic } \\
\text { residue }\end{array}$} \\
\hline & Temp range $\left({ }^{\circ} \mathrm{C}\right)$ & $\mathrm{n}^{*}$ & Mass loss & $\begin{array}{c}\text { Total } \\
\text { Mass loss }\end{array}$ & Assignment & \\
\hline (3) $\left[\left(\mathrm{CuCl}_{2}\right)_{2}(\mathrm{HL})\left(\mathrm{H}_{2} \mathrm{O}\right)_{4}\right] \cdot \mathrm{H}_{2} \mathrm{O}$ & $\begin{array}{c}30-220 \\
220-520 \\
520-700\end{array}$ & 3 & $\begin{array}{l}20.2(20.6) \\
34.5(34.8) \\
24.7(25.1)\end{array}$ & $81.5(82.5)$ & $\begin{array}{c}4 \mathrm{H}_{2} \mathrm{O} \text { coord /lattice \& } \mathrm{C}_{6} \mathrm{H}_{6} \\
4 \mathrm{CL}_{4} \mathrm{C}_{6} \mathrm{H}_{6} \mathrm{NO} \\
\mathrm{C}_{3} \mathrm{H}_{4} \mathrm{~N}_{3} \mathrm{O}_{2} \mathrm{~S}_{2}\end{array}$ & $\mathrm{Cu}_{2} \mathrm{O}$ \\
\hline$(7)\left[\left(\mathrm{UO}_{2}\right)_{2}(\mathrm{HL})\left(\mathrm{NO}_{3}\right)_{4}\right] \cdot \mathrm{H}_{2} \mathrm{O}$ & $\begin{array}{c}35-210 \\
210-250 \\
250-680 \\
\end{array}$ & 3 & $\begin{array}{c}12.6(13.3) \\
25(25.2) \\
16.2(16.6) \\
\end{array}$ & $53.8(55.1)$ & $\begin{array}{c}\mathrm{H}_{2} \mathrm{O} \text { latice \& } \mathrm{NO}_{3} \& \mathrm{C}_{6} \mathrm{H}_{6} \\
3\left(\mathrm{NO}_{3}\right) \& \mathrm{C}_{6} \mathrm{H}_{6} \mathrm{NO} \\
\mathrm{C}_{3} \mathrm{H}_{4} \mathrm{~N}_{3} \mathrm{O}_{3} \mathrm{~S}_{2}\end{array}$ & $2 \mathrm{UO}_{2}+2$ \\
\hline
\end{tabular}

Table 7. Thermodynamic data for the thermal decomposition of the metal complexes $(3,7)$.

\begin{tabular}{|c|c|c|c|c|c|c|c|c|c|c|c|c|c|c|}
\hline \multirow[t]{2}{*}{ Complexes.Compd. No. } & \multirow[t]{2}{*}{$\begin{array}{c}\text { Decomp. } \\
\text { Temperature } \\
\left({ }^{\circ} \mathrm{C}\right)\end{array}$} & \multirow[t]{2}{*}{$\mathrm{Tp} / \mathrm{K}$} & \multicolumn{2}{|c|}{$\begin{array}{c}\Delta \mathrm{E}^{\star} \\
\left(\mathrm{K} \mathrm{J} \mathrm{mol}^{-1}\right)\end{array}$} & \multicolumn{2}{|c|}{$\mathbf{R}^{2}$} & \multicolumn{2}{|c|}{$A\left(S^{-1}\right)$} & \multicolumn{2}{|c|}{$\begin{array}{c}\Delta \mathrm{S}^{*} \\
\left(\mathrm{~J} \mathrm{~K}^{-1} \mathrm{~mol}^{-1}\right)\end{array}$} & \multicolumn{2}{|c|}{ 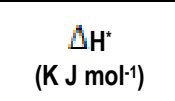 } & \multicolumn{2}{|c|}{$\begin{array}{c}\Delta \mathrm{G}^{*} \\
\left(\mathrm{~K} \mathrm{~J} \mathrm{~mol}^{-1}\right)\end{array}$} \\
\hline & & & CR & HM & CR & HM & CR & HM & CR & HM & CR & HM & CR & HM \\
\hline \multirow[t]{3}{*}{$(3)\left[\left(\mathrm{CuCl}_{2}\right)_{2}(\mathrm{HL})\left(\mathrm{H}_{2} \mathrm{O}\right)_{4}\right] \cdot \mathrm{H}_{2} \mathrm{O}$} & $438-510$ & 465 & 343.58 & 352.79 & 0.085 & 0.885 & $9.3 \times 10^{38}$ & $8.2 \times 10^{39}$ & 497.45 & 515.58 & 339.71 & 348.92 & 108.34 & 109.12 \\
\hline & $510-605$ & 565 & 181.76 & 51.32 & 0.992 & 0.993 & $4.8 \times 10^{16}$ & $1.1 \times 10^{9}$ & 74.57 & 72.07 & 179.32 & 48.88 & 157.5 & 69.97 \\
\hline & $605-923$ & 858 & 665.52 & 314.8 & 0.82 & 0.83 & $3.9 \times 10^{40}$ & $1.3 \times 10^{28}$ & 528.78 & 287.99 & 660.65 & 30.99 & 352.19 & 141.31 \\
\hline \multirow[t]{2}{*}{$(7)\left[\left(\mathrm{UO}_{2}\right)_{2}(\mathrm{HL})\left(\mathrm{NO}_{3}\right)_{4}\right] \cdot \mathrm{H}_{2} \mathrm{O}$} & $301-32$ & 319 & 368.28 & 381.79 & 0.97 & 0.96 & $4.7 \times 10^{6}$ & $1.3 \times 10^{63}$ & 916.13 & 963.06 & 365.63 & 379.14 & 73.14 & 71.66 \\
\hline & $324-457$ & 451 & 602.21 & 95.62 & 0.93 & 0.94 & $8.1 \times 10^{69}$ & $3.8 \times 10^{28}$ & 109.79 & 306.50 & 600.73 & 94.14 & 405.03 & 39.49 \\
\hline
\end{tabular}

Activation energy $\left(E^{*}\right), \quad$ enthalpy $\left(\Delta \mathrm{H}^{*}\right)$, entropy $\left(\Delta \mathrm{S}^{*}\right)$ and Gibbs free energy change of the decomposition $\left(\Delta \mathrm{G}^{*}\right)$ are the thermodynamic activation parameters of decomposition processes of complexes are evaluated graphically by employing the Coats-Redfern relation ${ }^{(47)}$ and HorowitzMetzger ${ }^{(48)}$. The entropy of activation $\left(\Delta \mathrm{S}^{*}\right)$, enthalpy of activation $\left(\Delta \mathrm{H}^{*}\right)$ and the free energy change of activation $\left(\Delta \mathrm{G}^{*}\right)$ were calculated, by using Excel computer program for complexes. The data are summarized in Table 7 .The high values of the activation energies reflect the thermal stability of these complexes. The entropy of activation is found to have a positive values in the complexes which indicate that the decomposition reactions unspontaneous$1 \mathrm{y}^{(38)}$. From the data Table 7, it was found the $\left(\Delta H^{*}\right)$ value and its sign, is dependent on the heat of formation of the complexes and the solvent effect ${ }^{(42)}$, in all cases, it is found that the $\left(\Delta \mathrm{H}^{*}\right)$ are positive values, So the reaction is endothermic ${ }^{(49)}$. 


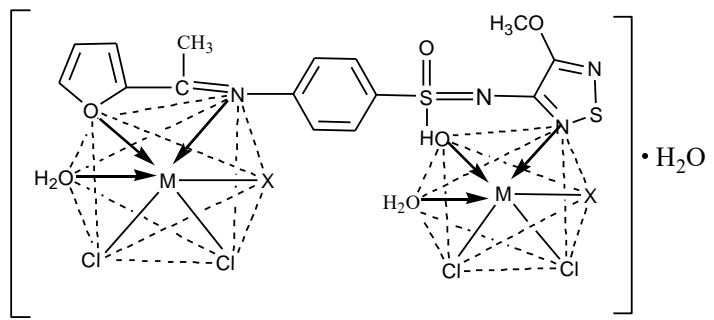

$\mathrm{M}=\mathrm{Fe}(\mathrm{III}), \mathrm{X}=\mathrm{Cl}$

$\mathrm{M}=\mathrm{Cu}(\mathrm{II}), \mathrm{X}=\mathrm{H} 2 \mathrm{O}$

$\mathrm{M}=\mathrm{Zn}(\mathrm{II}), \mathrm{X}=\mathrm{H} 2 \mathrm{O}$

$\mathrm{M}=\mathrm{Cd}(\mathrm{II}), \mathrm{X}=\mathrm{H} 2 \mathrm{O}$

$\mathrm{M}=\mathrm{Ce}(\mathrm{III}), \mathrm{X}=\mathrm{H} 2 \mathrm{O}$
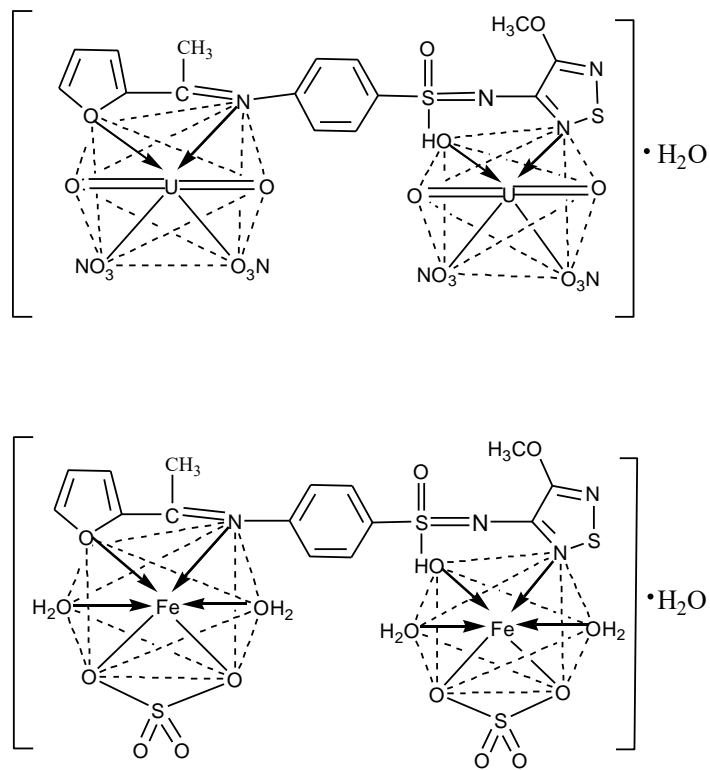

Fig.4. The suggested structures of the newly metal complexes. 


\subsection{Transmission electron microscopy (TEM)}

Transmission electron microscopy (TEM) is used to describe the size and shape of all nano-sized samples copper and zinc nanoparticles of HL Schiff base ligand Figs. 5, 6.

The size and morphology of copper and zinc nanoparticles (CuNPs, ZnNPs) with HL Schiff base ligand were investigated by TEM (Transmission electron microscopy) as show in Figs. 5, 6. The TEM images indicate that the copper and zinc nanoparticals show spherical shape with core shells of the Schiff-base ligands $^{(49)}$.

The TEM images further revealed the stabilization of copper and zinc nanoparticles due to interaction with the (HL) ligand. This stabilization facilitates penetration of tumor cell membrane and cause the destruction of tumor cell by CuNPs and ZnNPs ${ }^{(50,51)}$. The CuNPs and ZnNPs sizes are of 50, $60 \mathrm{~nm}$ respectively.

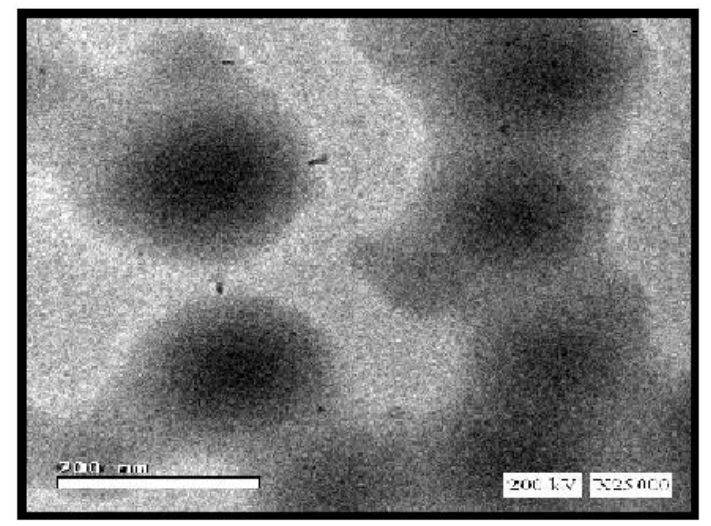

Fig. 5.TEM of CuNps with HL Schiff base ligand.

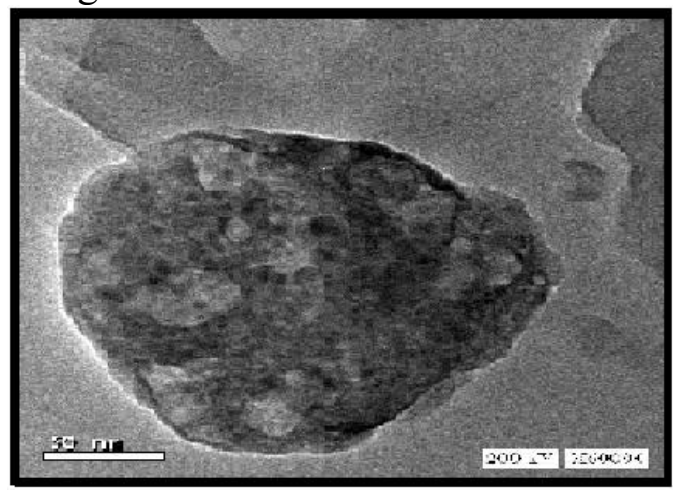

Fig. 6. TEM of ZnNps with HL Schiffbase ligand .

\subsection{Antimicrobial activity}

The main aim of the production and synthesis of any antimicrobial compound is to inhibit the causal microbe without any side effects on the patients ${ }^{(53)}$.

The antimicrobial activity of the parent Schiff base ligand HL and its metal complexes, copper and zinc nano particle size (CuNps,ZnNps) against microorganism, Gram positive(+ve) bacteria; Staphylo-coccus aureus (ATCC 25923) and Bacillus subtilis (ATCC 6635), Gram negative (-ve) bacteria Salmonella typhimurium (ATCC 14028) and Escherichia coli (ATCC 25922), yeast; Candida albicans (ATCC 10231) and fungi; Aspergillus fumigatus was tested in order to assess their potential antimicrobial agents.

The biological activity of the Schiff base ligand HL and its metal complexes (1-7), copper and zinc nano particle size (CuNps,ZnNps) were also compared with Chloramphenicol and Cephalothin which were used as standard antibacterial control and Cyloheximide as standard yeasts and fungi control. The data are listed in Tables 8,9 and Figs.7-12. According to the data it can be seen that the HL Schiff base ligand show approximately high activity towards Gram (+ve), Gram(-ve) strains of bacteria and towards Yeasts and Fungi, while all the complexes showed high activity towards Gram positive $(+\mathrm{ve})$ bacteria; Staphylo-coccus aureus (ATCC 25923) and Bacillus subtilis (ATCC 6635), Gram negative (-ve) bacteria Salmonella typhimurium (ATCC14028) and Escherichia coli (ATCC 25922).

The orders of the activity of the metal complexes of HL Schiff base ligand was as follows:

In case of Staphylococcus aureus (ATCC 25923):

$\mathrm{Ce}(\mathrm{III})>\mathrm{Fe}(\mathrm{II})>\mathrm{Cd}(\mathrm{II})>\mathrm{Fe}(\mathrm{III})>\mathrm{UO}_{2}$ (II)

$>\mathrm{Zn}(\mathrm{II})$.

In case of Bacillus subtilis(ATCC6635):

$\mathrm{Cd}$ (II) $>\mathrm{Ce}$ (III) $>\mathrm{UO}_{2}$ (II) $>\mathrm{Fe}$ (III) $>\mathrm{Cu}$ (II) $>$

$\mathrm{Fe}(\mathrm{II})>\mathrm{Zn}$ (II). 
In case Salmonella typhimurium(ATCC14028):

$\mathrm{Ce}(\mathrm{III})>\mathrm{Cd}(\mathrm{II})>\mathrm{Fe}(\mathrm{II})>\mathrm{Zn}(\mathrm{II})>\mathrm{Fe}(\mathrm{III})$.

In case of Escherichia coli(ATCC 25922):

$\mathrm{Cd}$ (II) $>\mathrm{Fe}$ (III) $>\mathrm{Zn}$ (II) $>\mathrm{UO}_{2}$ (II) $>\mathrm{Fe}$ (II) $>$ $\mathrm{Cu}$ (II) $>\mathrm{Ce}$ (III).

On the other hand, all metal complexes (1-7) have intermediate activity towards Yeast; Candida albicans (ATCC 10231) and Fungi; Aspergillus fumigatus.

The orders of the activity of the metal complexes was as follows:

In case of Candidaalbicans(ATCC10231):

$\mathrm{Cd}(\mathrm{II})>\mathrm{Cu}(\mathrm{II})>\mathrm{UO}_{2}$ (II) $>\mathrm{Fe}($ III $)>\mathrm{Zn}(\mathrm{II})>$

$\mathrm{Fe}(\mathrm{II})>\mathrm{Ce}(\mathrm{III})$.

In case of Aspergillus fumigatus:

$\mathrm{Fe}(\mathrm{III})>\mathrm{Cd}(\mathrm{II})>\mathrm{Cu}$ (II) $>\mathrm{Ce}$ (III) $>\mathrm{UO}_{2}(\mathrm{II})$.

The copper nanocompoite ( $\mathrm{CuNps})$ records high activity towards Gram positive(+ve) bacteria; Staphylococcus aureus (ATCC 25923) and Bacillus subtilis (ATCC 6635), Gram negative (-ve) bacteria Salmonella typhimurium (ATCC 14028) and Escherichia coli (ATCC 25922), Yeast; Candida albicans (ATCC 10231) and Fungi; Aspergillus fumigatus. Although zinc nanocomposite ( $\mathrm{ZnNps}$ ) reveals intermediate activity towards Gram positive $(+v e)$ bacteria, while its discourage the activity of its parent HL Schiff base ligand,Gram negative (-ve) bacteria, Yeast and Fungi.

So the order of the activity of the metal complexes was as follows:

In case of Staphylococcus aureus (ATCC 25923):

CuNps $>$ ZnNps $>$ HL $>$ Zn(II)complex.

In case of Bacillus subtilis(ATCC 6635):

$\mathrm{CuNps}>\mathrm{HL}>\mathrm{ZnNps}>\mathrm{Cu}(\mathrm{II})$ complex $>$ $\mathrm{Zn}$ (II)complex.

In case of Salmonella typhimurium (ATCC 14028):
$\mathrm{CuNps}>\mathrm{Zn}(\mathrm{II})$ complex $>\mathrm{ZnNps}=\mathrm{Cu}(\mathrm{II})$

complex $=$ HL.

In case of Candida albicans(ATCC 10231):

CuNps $>\mathrm{Zn}(\mathrm{II})$ complex $>\mathrm{Cu}(\mathrm{II})$ complex $=$ $\mathrm{HL}>\mathrm{ZnNps}(\mathrm{NA})$.

In case of Aspergillus fumigatus:

$\mathrm{CuNps}>\mathrm{HL}>\mathrm{Cu}$ (II)complex $>\mathrm{Zn}$ (II)complx

(NA) $=\mathrm{ZnNps}(\mathrm{NA})$.

Table 8. Antimicrobial activity of HL Schiff base ligand and its complexes (1-7).

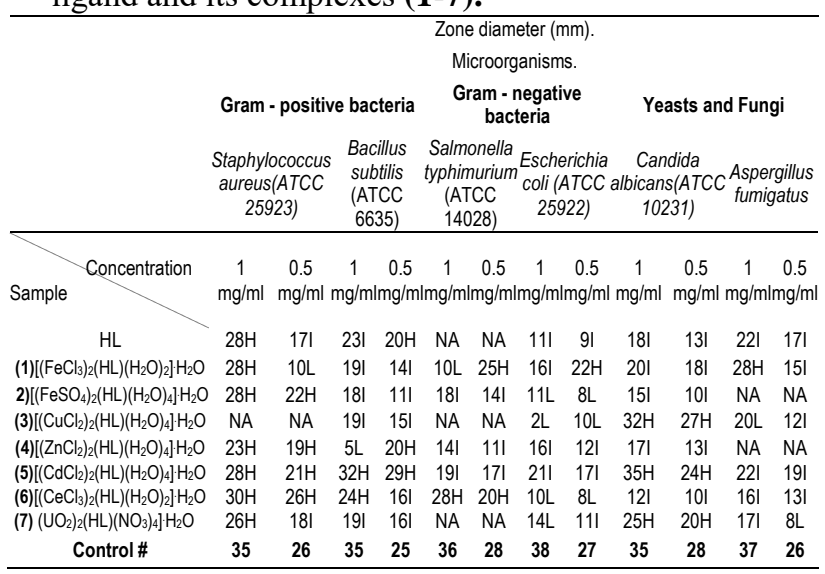

$\mathrm{NA}=$ No activity; L: Low activity; I: Intermediate activity; H: High activity.

\#: Chloramphencol in the case of Gram-positive bacteria, Cephalothin in the case of Gram-negative bacteria and cycloheximide in the case of Yeasts and Fungi.

Table. 9. Antimicrobial activity of HL Schiff base ligand, its complexes $(3,4)$ and

nanocompsite(CuNps, $\mathrm{ZnNps})(\mathbf{1}, \mathbf{2})$.

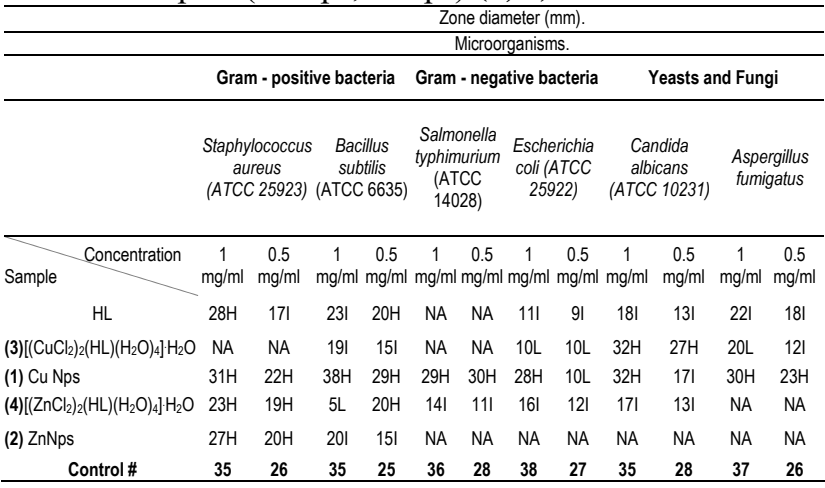

$\mathrm{NA}=$ No activity; L: Low activity; I: Intermediate activity; H: High activity.

\#: Chloramphencol in the case of Gram-positive bacteria,

Cephalothin in the case of Gram-negative bacteria and

cycloheximide in the case of Yeasts and Fungi. 


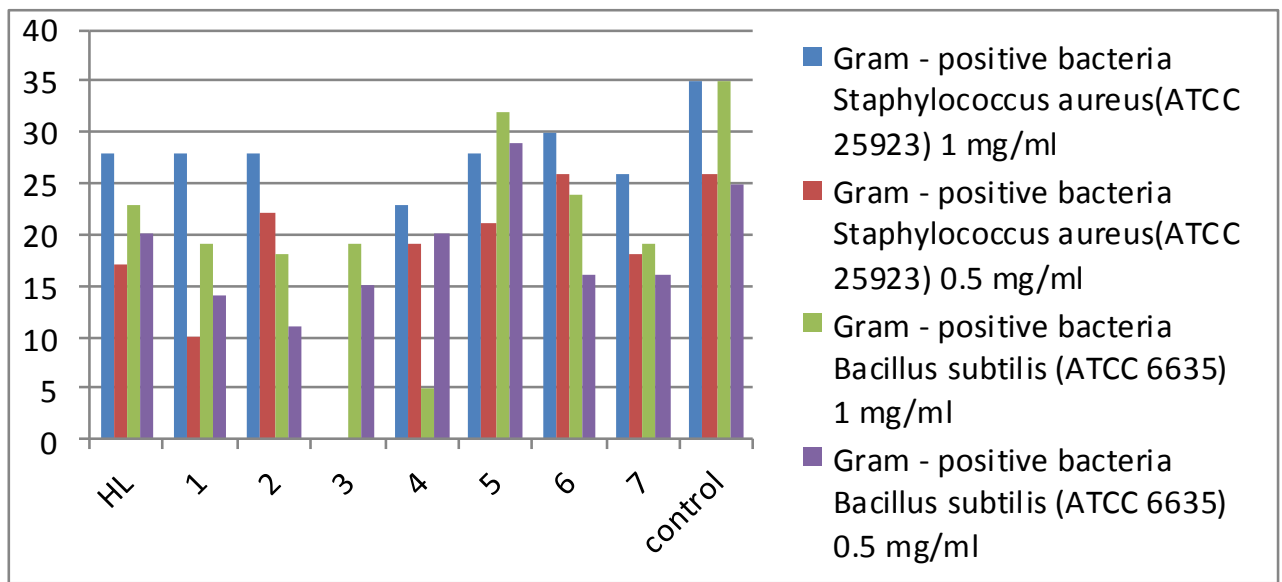

Fig. 7. Antibacterial activity of HL Schiff base ligand and its metal complexes(1-7) against Gram (+ve) bacteria

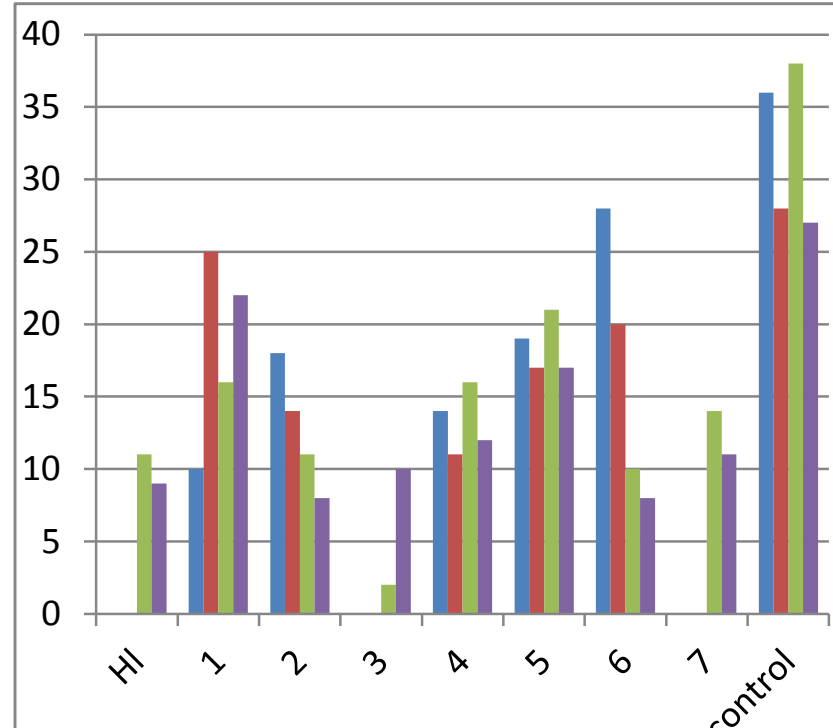

Gram - negative bacteria Salmonella typhimurium (ATCC 14028) $1 \mathrm{mg} / \mathrm{ml}$

Gram - negative bacteria Salmonella typhimurium (ATCC 14028) $0.5 \mathrm{mg} / \mathrm{ml}$

Gram - negative bacteria Escherichia coli (ATCC 25922) $1 \mathrm{mg} / \mathrm{ml}$

- Gram - negative bacteria Escherichia coli (ATCC 25922) $0.5 \mathrm{mg} / \mathrm{ml}$

Fig. 8. Antibacterial activity of HL Schiff base ligand and its metal complexes(1-7) against Gram (-ve) bacteria.

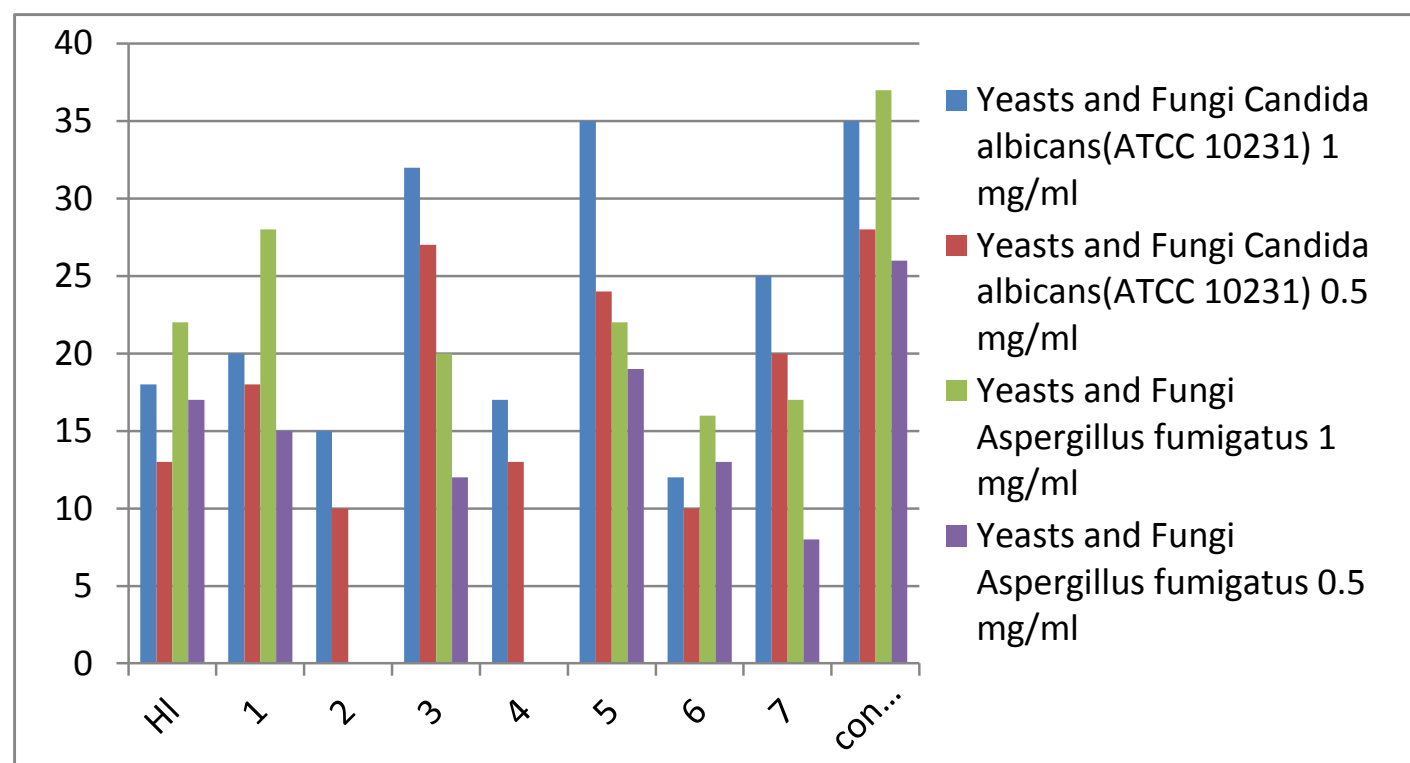

Fig.9. Antibacterial activity of HL Schiff base ligand and its metal complexes(1-7) against Yeasts and Fungi. 


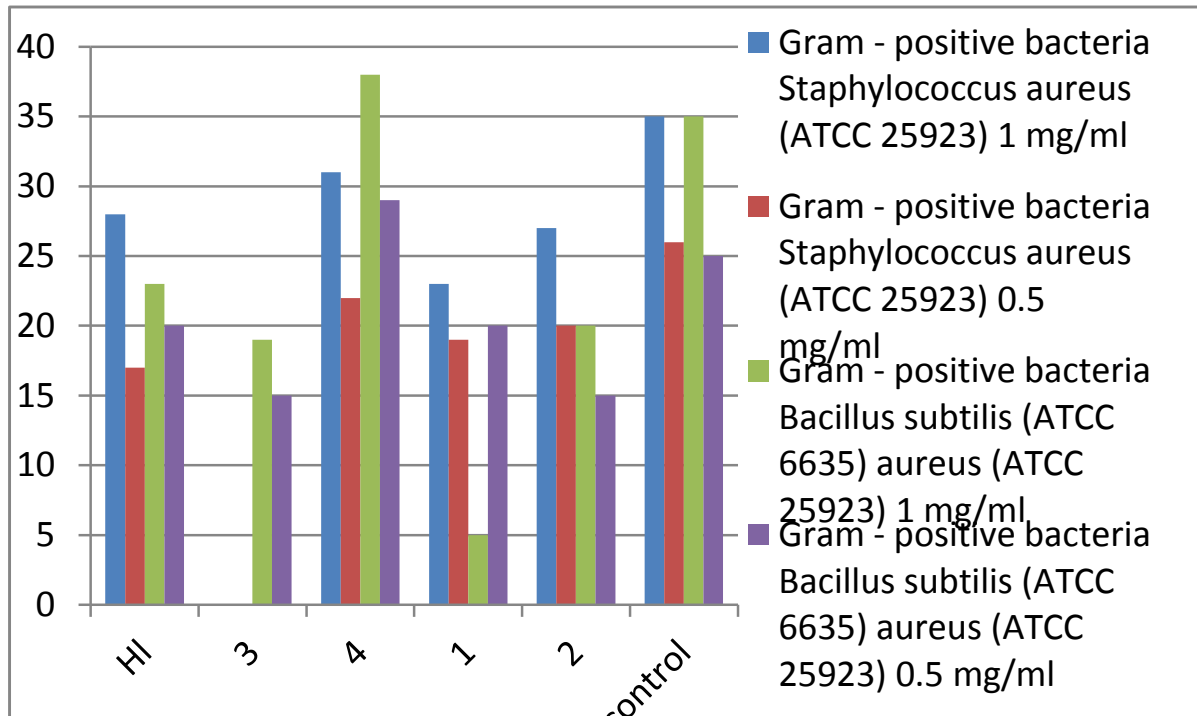

Fig. 9. Antibacterial activity of HL Schiff base ligand and its metal complexes, CuNps and ZnNps $(\mathbf{3 , 4}, \mathbf{1}, \mathbf{2})$ against Gram $(+\mathrm{ve})$ bacteria.

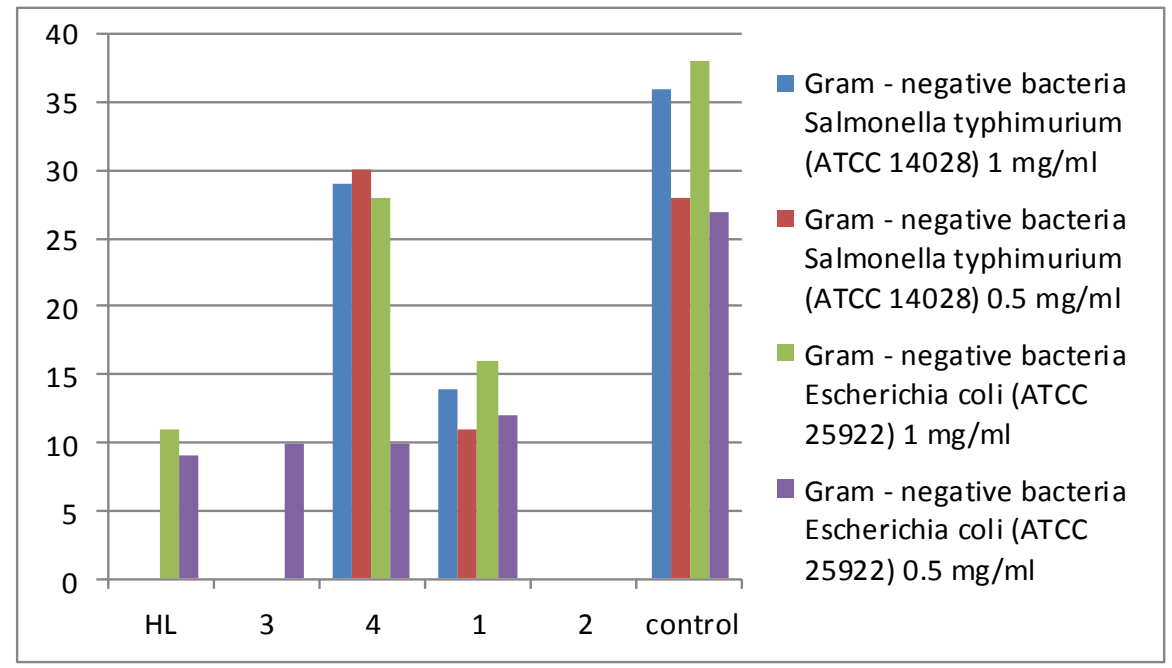

Fig . 11. Antibacterial activity of HL Schiff base ligand and its metal complexes, CuNps and $\mathrm{ZnNps}(\mathbf{3}, \mathbf{4}, \mathbf{1 , 2})$ against Gram (-ve) bacteria .

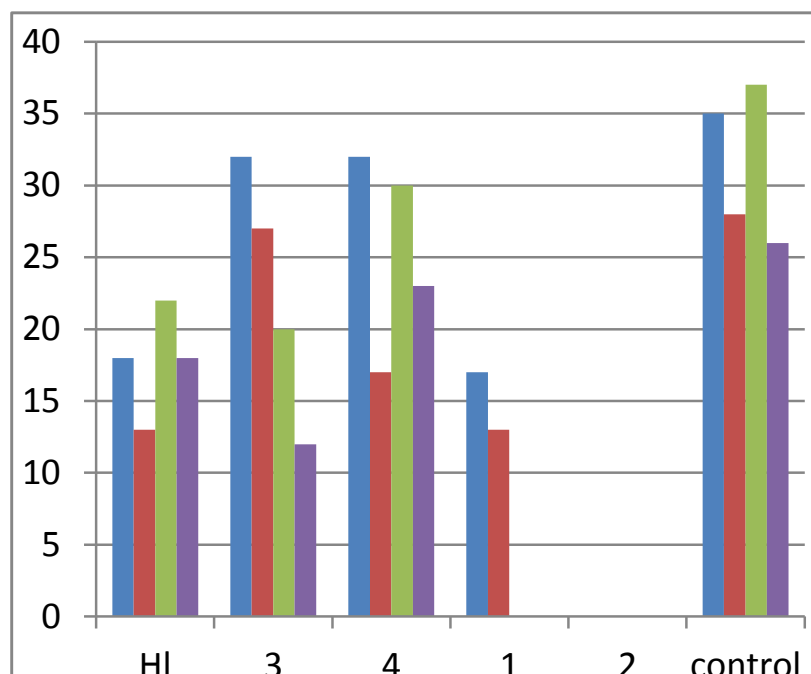

- Yeasts and Fungi Candida albicans (ATCC 10231) 1 $\mathrm{mg} / \mathrm{ml}$

- Yeasts and Fungi Candida albicans (ATCC 10231)

$0.5 \mathrm{mg} / \mathrm{ml}$

Yeasts and Fungi

Aspergillus fumigatus (ATCC 10231) $1 \mathrm{mg} / \mathrm{ml}$

Yeasts and Fungi

Aspergillus fumigatus (ATCC 10231) $0.5 \mathrm{mg} / \mathrm{ml}$

HI $\quad 3 \quad 4 \quad 1 \quad 1 \quad 2$ control

Fig .12. Antibacterial activity of HL Schiff base ligand and its metal complexes and CuNps and $\mathrm{ZnNps}(\mathbf{3}, \mathbf{4}, \mathbf{1 , 2})$ against yeasts and fungi. 
3.10 . In-vitro cytotoxicity assays. Evaluation of new synesized ligands and their metal complexes in cancer therapy.

In this study in vitro anticancer activity evaluation of the newly synthesized compounds HL Schiff base ligand and its metal complexes and copper, zinc nanocomposites (CuNps,ZnNps) was carried out against human cancer cell line (HCT116) (human colon cancer cell liens) also, called colorectal cancer or bowel cancer, which is the third most common form of cancer $^{(54)}$.The relationship between drug concentrations and cell viability was plotted to calculate $\mathrm{IC}_{50}(\mu \mathrm{g})$ (the value which corresponds to the concentration required for $50 \%$ inhibition cell viability) and the data were presented in Table 11. Almost all tested compounds are effective against HCT-116 (Colon cancer). The data illustrate that:
The HL Schiff base ligand inhibition against HCT-116 cell line records 59.69\%, while its copper and zinc nanocomposite (CuNps,ZnNps)records the highest inhibition equal to $93.96 \%$.

Also the $\mathrm{IC}_{50}$ values for HL Schiff base ligand, its complexes and nanoconposites were presented in Table 11 .The data shows that the copper nanocomposit $(\mathrm{CuNps})$ have the highest $\mathrm{IC}_{50}$ value equal to $2.60 \mu \mathrm{g}$ against colon carcinoma cell line HCT-116, while its HL Schiff base ligand records $\mathrm{IC}_{50}$ equal to $32.42 \mu \mathrm{g}$.

The data records that the order of the anticancer activities is:

$\mathrm{CuNps}=\left[\left(\mathrm{CuCl}_{2}\right)_{2}(\mathrm{HL})\left(\mathrm{H}_{2} \mathrm{O}\right)_{4}\right] \cdot \mathrm{H}_{2} \mathrm{O}>$ $\mathrm{ZnNps}>\left[\left(\mathrm{CeCl}_{3}\right)_{2} \quad(\mathrm{HL})\left(\mathrm{H}_{2} \mathrm{O}\right)_{2}\right] \cdot \mathrm{H}_{2} \mathrm{O} \quad>$ $\left[\left(\mathrm{ZnCl}_{2}\right)_{2}(\mathrm{HL})\left(\mathrm{H}_{2} \mathrm{O}\right)_{4}\right] . \quad \mathrm{H}_{2} \mathrm{O}>\mathrm{HL}>\left[\left(\mathrm{UO}_{2}\right)_{2}\right.$ $\left.(\mathrm{HL})\left(\mathrm{NO}_{3}\right)_{4}\right] \cdot \mathrm{H}_{2} \mathrm{O}$.

Tabel 10. Antitumor activity of $\mathrm{HL}$ ligand $\mathrm{Cu}(\mathrm{II}), \mathrm{Zn}(\mathrm{II}), \mathrm{Ce}(\mathrm{III})$ andUO $\mathrm{O}_{2}$ (II) complexes, $\mathrm{CuNps}$ and $\mathrm{ZnNps}$.

\begin{tabular}{cc}
\hline & HCT-116 \\
\hline Samples & Inhibition\% \\
HL & 59.69 \\
(3) $\left[\left(\mathrm{CuCl}_{2}\right)_{2}(\mathrm{HL})\left(\mathrm{H}_{2} \mathrm{O}\right)_{4}\right] \cdot \mathrm{H}_{2} \mathrm{O}$ & 89.81 \\
(4) $\left[\left(\mathrm{ZnCl}_{2}\right)_{2}(\mathrm{HL})\left(\mathrm{H}_{2} \mathrm{O}\right)_{4}\right] \cdot \mathrm{H}_{2} \mathrm{O}$ & 80.81 \\
(6) $\left[\left(\mathrm{CeCl}_{3}\right)_{2}(\mathrm{HL})\left(\mathrm{H}_{2} \mathrm{O}\right)_{2}\right] \cdot \mathrm{H}_{2} \mathrm{O}$ & 84.25 \\
(7) $\left[\left(\mathrm{UO}_{2}\right)_{2}(\mathrm{HL})\left(\mathrm{NO}_{3}\right)_{4}\right] \cdot \mathrm{H}_{2} \mathrm{O}$ & 31.82 \\
(1) $\mathrm{Cu} \mathrm{Nps}$ & 93.96 \\
(2) $\mathrm{Zn} \mathrm{Nps}$ & 91.38 \\
\hline
\end{tabular}

Tabel 11. Inhibition of cell proliferation $\left(\mathrm{IC}_{50} \mu \mathrm{g}\right)$ for $\mathrm{HL}$ free ligand, its metal complexes and nanocomposites(CuNps, $\mathrm{ZnNps})$.

\begin{tabular}{|c|c|}
\hline \multicolumn{2}{|c|}{ HCT-116 } \\
\hline Samples & $\mathrm{IC}_{50}(\mu \mathrm{g})$ \\
\hline $\mathrm{HL}$ & 32.42 \\
\hline (3) $\left[\left(\mathrm{CuCl}_{2}\right)_{2}(\mathrm{HL})\left(\mathrm{H}_{2} \mathrm{O}\right)_{4}\right] \cdot \mathrm{H}_{2} \mathrm{O}$ & 5.81 \\
\hline (4) $\left[\left(\mathrm{ZnCl}_{2}\right)_{2}(\mathrm{HL})\left(\mathrm{H}_{2} \mathrm{O}\right)_{4}\right] \cdot \mathrm{H}_{2} \mathrm{O}$ & 19.23 \\
\hline (6) $\left[\left(\mathrm{CeCl}_{3}\right)_{2}(\mathrm{HL})\left(\mathrm{H}_{2} \mathrm{O}\right)_{2}\right] \cdot \mathrm{H}_{2} \mathrm{O}$ & 10.32 \\
\hline (7) $\left[\left(\mathrm{UO}_{2}\right)_{2}(\mathrm{HL})\left(\mathrm{NO}_{3}\right)_{4}\right] \cdot \mathrm{H}_{2} \mathrm{O}$ & 50 \\
\hline (1)Cu Nps & 2.60 \\
\hline (2)Zn Nps & 8.94 \\
\hline
\end{tabular}




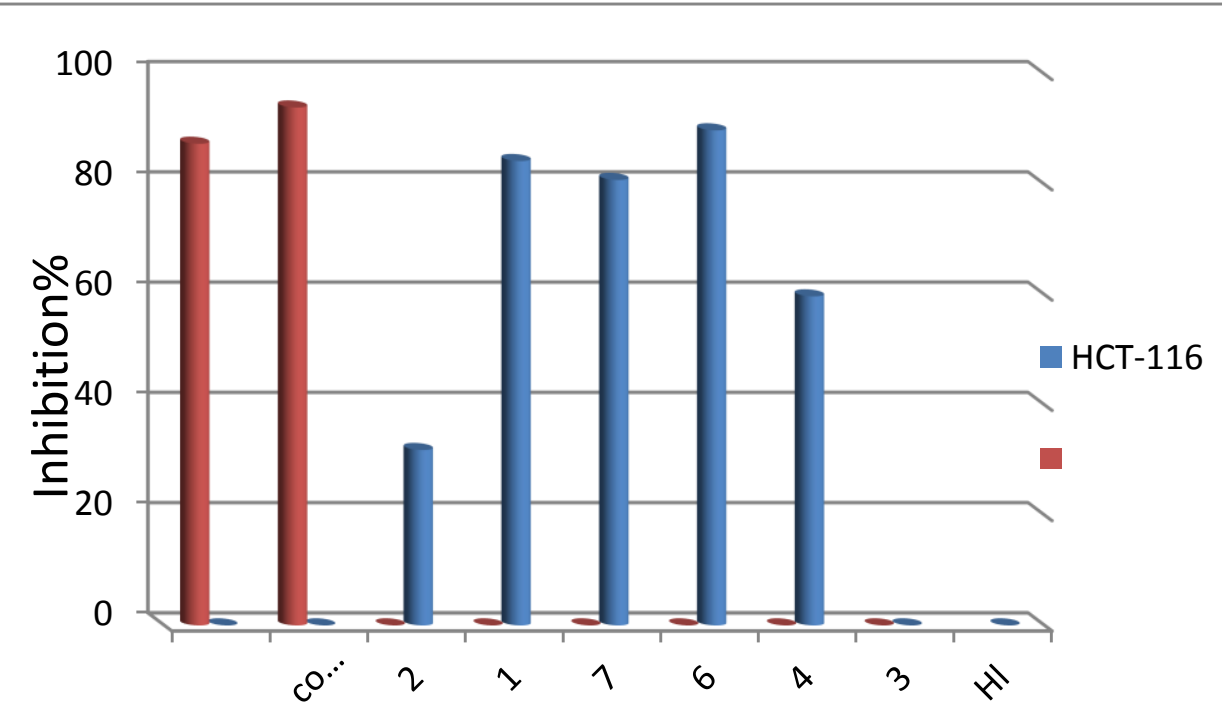

Fig.13. Antitumor activity of Schiff base ligand $\mathrm{HL}$ and $\mathrm{Cu}(\mathrm{II}), \mathrm{Zn}(\mathrm{II}), \mathrm{Ce}(\mathrm{III}), \mathrm{UO}_{2}$ (II) complexes, $\mathrm{CuNps}$ and $\mathrm{ZnNps}$.

\section{References}

1- Z. Hussain, E. Yousif and A. Altaie, Organic and medicinal Chemistry letters.,4, 1 (2014).

2- $\quad$ A.S. Abu-Khadra, R.S. Farag and A. E.M. Abdel-Hady, Ame. Journal of Analytical Chemistry, 7,233245(2016).

3- H.A.Bayoumi, A.M.A.Alaghaz and M.S.Aljahdali, Int. J. Electro Chem. Sci.,8, 9399-9413(2013).

4- S.K.Hadjikakou and N.Hdjiliadis, Coord. Chem. Rev.,253, 235-249 (2009).

5- A.Shokrollahi,M.Ghaedi,N.Khanjari, S. Noshadi and S. Joybar, E-Journal Chemistry,8(2), 495-506(2011).

6- O.Kocyigit and E.Gulcur, J.Incl. Phenom.Macrocyle.Chem., 67,287293(2010).

7- E.Ispir,Dyes and Pigments,82,13-19 (2009) .

8- V.L.Siji, M.R.Sudarsanakumar and S.Suma, Transition Metal Chemistry, 36, 417-424(2011).

9- S.Eswaran, A.V.AdhiKari and N.S. Shetty, Eur. Journal of Medicinal Chemistry,44, 4637-4647(2009).

10- P.H.C.Camargo,K.G.Satyanarayana and F.Wypych, Materials Research, 12, 1-39(2009).

11- A.R. Ibrahim, Int. J. Adv. Res., 3(8), 315- 324 (2015).

12- A.A. El-Sherif and T.M.A. Eldebss, Spectro Chim. Acta A, 97,1803-1814 (2011).

13- M.S. Refat, F.M. AlAzab, H.M. A. Al-Maydama, R.R. Amin and Y. M. S. Jamil, Journal of Molecular Structure, 1059, 208224 (2014).

14- A. Saxena, Adv. Appl. Sci. Res., 4 (4), 152-154 (2013).

15- I.P. Ejidike and P.A. Ajibade, Int. J. Mol. Sci., 17,60(2016).

16- A. Athar, F. Khan, W. Ahmed, Z. Hag and Z. Khan, Amer. Eur. J.Agric and Environ. Sci.,15(1),36-67(2015).

17- D.P. Patel, S.P. Prajapati, A.K. Rana and P.S. Patel, Der Chemical sinca., 3 (2),491-496 (2012).

18- G.G. Mohamed, M.A. Zayed and S.M. Abdallah, J. Molec. Struc., 979,6271(2010).

19- A.A. Alomari, J.Atoms and Molecules, 4(2), 693-704(2014).

20- M.E.Azab, S.A. Rizk and A.E.-G. Amr, Molecules, 20, 18201-18218 (2015). 
21- A.-N. M.A. Alaghaz, H. A. Bayoumi, Y. A. Ammar and S. A. Aldhlmani, J. Mol. Struct., 1035, 383-399(2013).

22- H. A. Bayoummi,A-N. M.A. Alaghaz, and M. S. Aljahdali, Int. J. Electrochem. Sci., 8, 9399-9413(2013).

23- B. Jain, S.Malik, N.Sharma and S. Sharma, Der Chemica Sinica., 4(5),4045(2013).

24- A. Jebali, F. Ramezani and B. Kazemi, J. Clust. Sci., 22, 225-232 (2011).

25- G.G. Mohamed, M.M.Omar, and A.M. Hindy, Turk., J. Chem., 30, 361-382 (2006).

26- G.G. Mohamed, Phosphrous Sulfur Silicon Related Elements, 180 (7), 1569(2005).

27- M. Asadi, M.S.Khah and A.H.Kianfar, J. Irna. Chem. Soc.,7(1), 38-44(2010).

28- M.S. Balakrishna, D. Suresh, A . Rai, J.T. Mague and D. panda, Inorg. Chem., 49,8790-8801(2010).

29- G.G. Mohamed and C.M. Sharaby, Spectro Chim. Acta, Part A, 66, 949 (2007).

30- C.M.Sharaby, Synth. and React. Inorg. Met. Org. and Nano-Met. Chem., 35, 133-142(2005).

31- K.Vimala, K. S. Sivudu,Y. M.Mohan, B.Sreedhar and K.M.Raju, Carbohydrate Polymers, 75, 463-471 (2009).

32- A.M.A. Alaghaz and R.A.Ammar,Eur. J.Med.Chem.,45,1314-1322 (2010).

33- A.Jain and S.Valecha, Acta Chim. Phrm. Indica., 5(2),55-59 (2015).

34- S. Sharma,N. Sharma, B. Jain and S. Malik, Der chemica Sinica., 5(5),6166(2014).

35- N. Nawar, I.I. El-Swwah, N.M. Hosny M. M. Mostafa, phosphorous, Sulfur and Silicon and related elements, 187,976(2012).

36- U. k. Singh, S.N. Pandeya, S. K. Sethia, M. Pandey, A. Singh, A. Garg and P. Kumar. Int.
J.Phamaceutical Sciences and Drug Research, 2(3), 216-218(2010).

37- A.A. Abdel Aziz, A.M. Salem, M.A. Sayed, and M.M. Aboaly, J. Mol. Struct., 1010, 130-138(2010).

38- A.M.A. Alaghez, B.A. El-Sayed and R.A.A. Ammar, Mol . Struct., 1035, 83-93(2013).

39- V.R.Solomon,C. Hua and H.Lec, Bioorg. Med. chem., 17, 7585(2009).

40- M. F. Hochella J. Nanoscience and technology, 203, 593-605 (2002).

41- G. G.Mohamed,N.E.A.El-Gamel and F. A. N.El-Dien, Synth. React. Inorg. Met. Org. Chem., 31(2), 347(2001).

42- E. Yousif, Lambert Academic, Saabrucken, (2012).

43- G.G.Mohamed, Phosphrous Sulfur Sinlicon related Elements ,180(7), 1569 (2005).

44- M.Odabasoglu, S.Cakmak, G.Turgut, and H. Icbudak, Phsphrous, Sulfur and Silicon, 178,549-558(2003).

45- K.Mohanan,C. J. Athira,Y. Sindhu and M.S. Sujamol,J. Rare Earths, 27(5), 705(2009).

46- W.H. Hegazy and I. H .Al-Motowaa, Bioinrg. Chem. Appls., 1,201(2011).

47- E. Kremer, G. Facchin, E. Estevez, P. Albores, E.J. Baran, J. Ellena and M.H. Torre, J. Inorg. Biochem, 100, 1167-1175 (2006).

48- S.S.Stokes, R.Albert, E. T.Buurman , Andrews B., A. B.Shapiro, O. M. Green, A.R.McKenzie and L.R. Otterbein, Bioorg and Med. Chem. Lett., 22, 7019 (2012).

49- N. Ozbek, H. Katircioglu, N. Karacan and T. Baykal, Bioorg. Med. Chem., 15, 5105-5109(2007).

50- M.Asadi, M.S. Khah and A.H.Kianfar, J.Iran .Chem. Soc., 7(1), 38-44 (2010).

51- G.E. Amer, Ph.D. Thesis, Faculty of Science, Ain-Shames University, Cairo, Egypt (2011). 
52- G.M.S.Elsharfei, F.Z. Yehia, O.I.H. Dimitry, A.M.Badwi and G. Eshaq, Applied Catalysis B: Envirometal, 99,242-247(2010).

53- M.M.H.Khalil, E.H.Ismail, G.G. Mohamed, E.M.Zayed and A.Bader, J. Inorg. Chem.,2,13-21(2012).

45- P.Skehan, R .Strreng and D. Scudiero, J .Nati . Cancer Inst., 82(13), $1107-$ 112(1990). 